\title{
La función social e ideológica de las fiestas religiosas: identidad local, control social e instrumento de dominación
}

\author{
The Role that Religious Festivities Have in Society \\ and Ideology: Local Identity, Social Control \\ and Instrument of Domination
}

\author{
José Fernando Domene Verdú ${ }^{1}$ \\ Investigador independiente
}

\section{RESUMEN}

El presente artículo intenta responder a la pregunta: ¿qué función tienen las fiestas religiosas y patronales en la sociedad, ahora y a lo largo de la Historia? Pertenecen a lo que se denomina religiosidad popular, son utilitaristas, porque se utilizaban como solución a las calamidades naturales y sanitarias, y son principalmente un símbolo de identidad local o regional. Pero, además, han tenido siempre una función social, que se podría resumir en el mantenimiento del orden social establecido mediante la identificación de parte de la población con la aristocracia dominante. El paralelismo entre Dios, la Virgen y los santos con los reyes, los señores feudales y los miembros de la nobleza en general favorecía que las mismas actitudes de obediencia y sumisión que el pueblo tenía hacia los personajes religiosos las tuviera también hacia los personajes de la sociedad feudal, la nobleza, el clero y la posterior monarquía absoluta. Las fiestas religiosas (Semana Santa, Navidad, Reyes Magos y, sobre todo, las fiestas patronales) eran, entonces, la manifestación cultural más idónea para propiciar que el pueblo llano adoptara estas actitudes hacia unos e, indirectamente, también hacia los otros.

Palabras clave: Religiosidad popular; Fiestas religiosas; Identidad local; Control social; Alienación.

\section{SUMMARY}

This article attempts to answer the question: what role have religious and patroness festivities in society, now and throughout history? They belong to what is called popular religiosity, are utilitarian — because they were used as a solution to natural and epidemic calamities - and are mainly a symbol of local or regional identity. But besides this, they have always had a social and ideological role, which can be summarized as maintaining the established social order, mainly by making that a part of the population identifies itself with the Crown and the ruling aristocracy. The parallel between God, the Virgin and the saints with the kings, feudal lords and members of the nobility in general favored that the same attitudes of obedience and submission that common people had toward the religious figures, they also had them to the social ruling figures

\footnotetext{
${ }^{1}$ Correo electrónico: joferdv@gmail.com. ORCID ID http://orcid.org/0000-0001-6793-5802.
} 
(the nobility, the clergy and the subsequent absolute monarchy). Therefore, religious festivities (Easter, Christmas, Kings and, especially, the patron-saints' festivities) were the most suitable cultural event to promote that the common people adopt these attitudes towards religious figures and, indirectly, also towards the civilian ones.

Key words: Popular Religiosity; Religious Festivities; Local Identity; Social Control; Alienation.

\section{INTRODUCCIÓN}

Las fiestas patronales y las fiestas religiosas en general han sido una de las manifestaciones culturales más importantes a lo largo de la Historia, y en cierto modo, todavía lo siguen siendo. Mucho se ha escrito sobre ellas. Sin embargo, a pesar de su carácter religioso, la Teología es incapaz de explicarlas de forma satisfactoria, y ha sido la Antropología social y cultural la que las ha explicado con mayor acierto y profundidad, debido a su carácter popular. No obstante, esa explicación antropológica sigue sin explicar numerosos aspectos de las fiestas religiosas y patronales. Su carácter identitario, por ejemplo, no explica por qué las fiestas religiosas y patronales tienen mucho mayor arraigo popular que otros símbolos identitarios locales o nacionales, o por qué siguen teniendo tanto arraigo popular en una sociedad mayoritariamente laica. Tampoco explica por qué los costaleros tienen que sufrir al llevar sobre sus hombros el peso de los pasos de la Semana Santa, ni por qué esos pasos, y las imágenes que sustentan, se adornan con tanto lujo y poseen tanto valor artístico, entre otras cosas. Para explicar todos esos aspectos de estas fiestas hay que recurrir a la Historia. Es el paralelismo entre los elementos festivos y los históricos y sociales lo que permite comprender su origen, desarrollo y características peculiares, ya que este tipo de fiestas ha tenido una función en la sociedad de cada período histórico. El método hermenéutico está vigente, pero los símbolos festivos se interpretan ahora teniendo en cuenta el paralelismo que tienen con los elementos e instituciones de la sociedad a lo largo de la Historia. Los resultados de este método son significativos y las conclusiones, claras y clarificadoras.

\section{LAS FIESTAS PATRONALES COMO MANIFESTACIÓN DE LA RELIGIOSIDAD POPULAR}

La mayoría de las fiestas actuales se celebran en honor de un santo o de una Virgen, que suele ser el Patrón o la Patrona de la localidad (Domene 1999, 2006, 2008 y 2015). Las fiestas patronales y la mayoría de las fiestas religiosas pertenecen a lo que actualmente se denomina religiosidad popular, que es la manera cómo la población vive y practica realmente la religión. S. Rodríguez Becerra (2011) considera más adecuado denominarla religión común ${ }^{2}$. El culto a la Virgen o a los santos, en calidad

\footnotetext{
2 "Considero que la religión común es la religión de la mayoría de los ciudadanos, y por ello la religión real de un pueblo, sin olvidar que actualmente sectores significativos en el mundo occidental no tienen ninguna religión; todo lo demás es superestructura dominante que en parte la ha conformado pero que no la ha modificado esencialmente. Así, persiste el modelo de relación diádica de los hombres con los seres y fuerzas sobrenaturales que aunque desigual, no es
} 
de Patronas o Patronos de las ciudades, es posible gracias al arraigo que tenían en la población y a la devoción con la que se veneraban ya desde épocas muy remotas, siendo la continuación de las prácticas religiosas precristianas, normalmente de religiones politeístas (en la Península Ibérica, íberas, celtas y romanas, principalmente), que fueron asimiladas por el cristianismo con el fin de conseguir la mayor difusión posible de este ${ }^{3}$ (Maldonado 1990: 61-62), igual que ha ocurrido después en África y América Latina, en lo que se conoce como inculturación, en el ámbito religioso, y aculturación, en el histórico y antropológico.

La Iglesia cristianizó, ya desde el principio, las fiestas paganas, haciendo coincidir las fechas de las fiestas cristianas con las de las principales fiestas prerromanas. De esta manera, se hicieron coincidir con los solsticios de invierno (la Navidad) ${ }^{4}$ y de verano (san

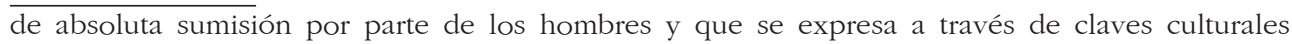
propias, una de cuyas manifestaciones más conocidas es la promesa. Por todo ello propongo denominar a las religiones comunes con apelativos de las sociedades y culturas, de ahí el título de mi libro: La Religión de los andaluces" (Rodríguez 2011: 40).

3 "Si nos remontamos aún más lejos en nuestra búsqueda de los orígenes, nos encontramos con una cuestión que hoy se comenta entre nosotros y que tiene su interés siempre que no se la extrapole universalizándola indebidamente. Me refiero a la cuestión de las influencias precristianas en la religiosidad española y en su piedad mariana; concretamente, a la posible influencia de las diosas-madres mediterráneas, llamadas también las Grandes Madres. Se trata de exhumar el sustrato, la arqueología de unos paganismos, de unas divinidades femeninas que, luego, son asumidas por una evangelización inculturizadora y transformadas en la realidad mariana. El anuncio apostólico habría buscado las afinidades de lo precristiano con la nueva fe, la "praeparatio evangelica", la "potentia oboedientialis" de las poblaciones ibéricas. Ello no tiene por qué ir en contra de la genuinidad cristiana de un pueblo, antes, al contrario, sirve para conocer la espesura histórica, la estratigrafía genealógica de un proceso de conversión. Las diosas de la fecundidad, dicen los especialistas, tenían fácil acogida en las poblaciones hispanas. La causa de tal receptividad parece que estuvo en el hecho de que una deidad de este carácter gozó de gran aceptación dentro de la Península ibérica durante el segundo milenio antes de Cristo (Edad de Bronce). Ha quedado constancia de ello en numerosos cilindros y placas que la representan. En la religión de los tartesos, asentados en la desembocadura del Guadalquivir, abundan las representaciones de la diosa Astarté, de origen fenicio-cananeo; así la llamada Astarté de Sevilla, del siglo VIII a. C. La más antigua reproducción de Astarté es la grabada en el cilindro-sello de VélezMálaga, obra siria del siglo XIV a. C. El nombre de la diosa egipcia Isis aparece por primera vez en occidente hacia el año 660 a. C., precisamente en España, concretamente en La Aliseda (Cáceres), grabado en una botella de cristal de roca tallado. Dentro de la cultura turdetana se registran otros muchos ejemplos de estas diosas. La Dama de Baza (siglo V a. C.), la de Elche, etc., son interpretaciones en este sentido. En Córdoba (Priego) y Jaén hay terracotas del siglo V que representan a la diosa Atenea. En fin, en el ámbito de la cultura creada por los iberos, especialmente en el Levante español, tenemos también terracotas del siglo II representando a la diosa-madre dando el pecho a un niño (La Serreta y la Albufereta). Puede tratarse de la diosa Tanit, es decir, la Astarté púnica" (Maldonado 1990: 61-62).

${ }^{4}$ "Qué consideraciones guiaron a las autoridades eclesiásticas para instituir la fiesta de Navidad? Los motivos para la innovación están declarados con gran franqueza por un escritor sirio cristiano: "La razón, nos dice, de que los Padres transfirieran la celebración del 6 de enero al 25 de diciembre fue esta: era costumbre de los paganos celebrar en el mismo día 25 de diciembre el nacimiento del sol, haciendo luminarias como símbolo de la festividad. En estas fiestas y solemnidades, tomaban parte también los cristianos. Por esto, cuando los doctores de la iglesia se dieron cuenta de que los cristianos tenían inclinación a esta fiesta, consultaron y resolvieron que la verdadera Navidad debería solemnizarse en ese mismo día, y la fiesta de la Epifanía en el 6 de enero. Por esa razón, y continuando la costumbre, se siguen encendiendo luminarias hasta el día 6\%. El origen pagano de la 
Juan), y con los equinoccios de primavera (san José y la Semana Santa) y de otoño (san Miguel). Pero, aunque las fiestas cristianas sustituyeron a las paganas, se conservaron en muchas de ellas los rituales de las antiguas fiestas precristianas (las hogueras de san Juan, por ejemplo), que a veces se continuaron celebrando solo con leves modificaciones onomásticas o simbólicas, pero conservando gran parte de aquellos rituales precristianos. Esta continuidad ha sido estudiada en varios tipos de fiestas de origen precristiano que se celebran en la actualidad, como por ejemplo las Cruces de Mayo 5 (Velasco 1982: 196202 y Rodríguez 1999), la Candelaria (Martínez y Campillo 2000), la Fiesta del Charco (Las Palmas) (Suárez 1999: 191-204), los lunes de Pascua de Cuevas y Santerón (Navarra) (Fernández 1999: 109, 131), entre otras muchas ${ }^{6}$.

La religiosidad popular es utilitarista, ya que era el remedio sobrenatural para la curación de las enfermedades y epidemias, es una creencia directa y concreta, que está desprovista por completo de conceptos teológicos abstractos ${ }^{7}$, y está basada en el culto a los santos y a las Vírgenes como los únicos seres (sobrenaturales) que pueden solucionar y remediar los problemas sanitarios y de otra índole de la población en la sociedad preindustrial ${ }^{8}$. Desde el punto de vista emic, la Iglesia ha interpretado

Navidad está claramente insinuado, si no tácitamente admitido, por san Agustín, cuando exhorta a los cristianos fraternalmente a no celebrar el día solemne en consideración al Sol, como los paganos, sino en relación al que hizo el Sol. De modo semejante, León el Grande condenó la creencia pestilente de ser la Navidad solemnizada por el nacimiento del nuevo Sol, como fue llamada, y no por la natividad de Cristo. Parece ser, pues, que la iglesia cristiana eligió la celebración del nacimiento de su fundador el día 25 de diciembre, con objeto de transferir la devoción de los gentiles del sol al que fue llamado después Sol de la Rectitud" (Frazer 1890: 415).

5 "Lo que llamamos cristianización es el resultado de la fuerte presencia organizada de la Iglesia expresada en una organización vertical: papas, concilios, obispos, vicarios y curas, y otra horizontal, las órdenes religiosas. En relación con las fiestas de la cruz, el árbol es sustituido por la cruz, pero estos cambios semánticos no han penetrado en la devoción popular (...). La cruz se empleó para desterrar el árbol de mayo romano por los sacerdotes cristianos en su intento de sustituir los ritos paganos que no podían abolir de otra manera. La fiesta forma parte de un catolicismo popular que más tarde se politizó y secularizó incorporando retratos y símbolos ajenos a la cruz: retratos de los guerrilleros Mina y El Empecinado, hoces y martillos, etc." (Rodríguez 1999: 51-53).

${ }^{6}$ Los orígenes paganos de algunas celebraciones es reconocido, entre otros, por san Agustín, cuando "exhorta a los cristianos a no celebrar el día solemne en consideración al sol, como los paganos, sino en relación al que hizo el sol" (Frazer 1890: 415). Unos y otros ejemplos nos llevan a la reflexión expuesta por Sir James George Frazer "con cuánta frecuencia la Iglesia se ha ingeniado tan habilidosamente para injertar el acodo de la nueva fe en el viejo tronco del paganismo" (Frazer 1890: 400).

7 "Supone una praxis poco intelectualista, con predominio del sentimiento y de la imaginación; es sobre todo una religión vivida y participativa, sin excluir las actitudes individuales. Muestra poco interés y comprensión por los misterios elaborados por los teólogos considerados verdades dogmáticas, así el Dios trinitario, la concepción inmaculada de María, la encarnación de Dios en mujer o el pecado original como herencia de los supuestos primeros padres. Igualmente, a la permanente sumisión a la divinidad preconizada por la Iglesia opone el do ut des, es decir, te doy para que me des, tan claramente expresado en la promesa y el exvoto. Se da asimismo una gran importancia al milagro. El hombre reconoce sus limitaciones como animal racional y espera de los poderes sobrenaturales la solución de sus problemas que no puede solventar con sus propios recursos" (Rodríguez 2011: 39).

8 "Está asimismo dirigida a satisfacer las necesidades primarias: salud, trabajo, protección contra las catástrofes y fertilidad; tiene un sentido pragmático pues busca el beneficio y la respuesta a las necesidades más perentorias; para obtener estos fines ofrece compensaciones a los seres sobrenaturales y hace ofrendas propiciatorias como inversión de futuro" (Rodríguez 2011: 39). 
la función de los santos y a las Vírgenes como mediadores entre Dios y los hombres, ya que Dios enviaba a los hombres las enfermedades y epidemias como castigos por sus pecados, y había que pedirle a algún intermediario, que tuviera influencia sobre él para poder aplacar su ira, para que cesara en su castigo y tuviera misericordia de sus criaturas. Y, ¿quién mejor que su madre, la Virgen, o los santos, como personas de vida ejemplar, para realizar esa mediación? Sin embargo, en la religiosidad popular no se concibe realmente esta intermediación de la Virgen o de los santos ante Dios, sino que, a quien realmente pedían los fieles el cese de las enfermedades y epidemias, era a la Virgen o a los santos, ya que la intermediación con Dios es un concepto demasiado abstracto para la mayoría de la población, que hasta el siglo XX era mayoritariamente analfabeta, y sobre todo para los que no tenían una formación teológica, que era la mayoría de la gente?. De esta manera, cada santo o cada Virgen es capaz de curar determinadas enfermedades o catástrofes, y no otras (santa Bárbara para las tormentas, san Gregorio contra las plagas de langosta, san Blas contra la difteria, la Virgen de las Virtudes contra la peste, etc., etc.). Se trata, por tanto, de un auténtico politeísmo cristiano, que además es claramente utilitarista, ya que tiene la función de solucionar los problemas graves de la gente. Las fiestas patronales, basadas en la religiosidad popular, venían a ser, por tanto, la única solución que encontraba la sociedad feudal a la que aferrarse para intentar evitar las calamidades sanitarias (epidemias) o climatológicas (sequías) que sufrían cíclicamente nuestros antepasados como consecuencia de las crisis de subsistencias, escasez de alimentos y hambrunas, $\tan$ usuales en aquel tipo de sociedad ${ }^{10}$ (Maldonado 1990: 72-73).

9 "Otro elemento dominante, frente a las reservas luteranas, es la función de la Virgen como intercesora: una derivación de la madre comprensiva y compasiva que pudiera atemperar la majestuosidad del Cristo pantocrátor en su solio de juez. En Reflejos esclarecidos... esta faceta mariana se impone de manera evidente sobre todas las otras. Nótese, sin embargo, que su actuación va a menudo un paso más allá de la mera mediación, pues no es infrecuente que se la presente como autora autosuficiente y eficacísima de los milagros que se le achacan a favor de sus fervientes devotos —un exceso contra el que clamó Lutero—- y a la que estos se dirigen en la plena confianza de su actuación. Resulta curiosa la seguridad con que los necesitados de su ayuda la esgrimen contra sus enemigos; en este caso Lucifer, los endemoniados que personifican el mal absoluto que aquel encarna, o los creyentes de otras religiones" (Prieto y Domene 2014: 41-42).

10 "Dentro de esta religiosidad local del siglo XVI español, lo que constituye su núcleo central es el santo patrono y el voto o la promesa. La relación de ambos es fácil de explicar. Ante los azares de la vida de entonces, a saber, las epidemias, las plagas, los desastres económicos por pedriscos o sequías, los pueblos acudían a los santos como intercesores y "abogados" ante Dios, el juez supremo. A cambio, les ofrecían un voto o promesa, es decir, el compromiso de celebrar un día de fiesta en su honor, observando la víspera abstinencia de comer carne, haciendo obras de caridad y homenajeando al santo con una procesión. Nuestro antropólogo comenta cómo se concebían los vínculos humano-divinos al modo de una relación judicial (entre abogados y jueces), paralela a las relaciones existentes en la justicia humana, por ejemplo en las Cancillerías de Valladolid o Granada, adonde los procuradores acudían continuamente en demanda de reducción de tasas, de liberación de dependencias del señor o por litigios, de resolución de litigios por tierras comunes, etc. Estas relaciones se apoyan pues en una relación de intercambio por la cual se entiende que un santo determinado acepta convertirse en intercesor de una comunidad local y, por tanto, en su salvaguarda. Por su parte, la comunidad contrae el compromiso de honrarle, al tiempo que reafirma su entidad como comunidad. Como horizonte de fondo podemos constatar aquí una mentalidad popular-teológica articulada en torno a dos polos: el castigo y la gracia. Las gentes de esta época imaginaban a Dios como un poder exterior severo que, cuando 
Esta interpretación emic de las catástrofes naturales como castigos divinos explica, por tanto, la necesidad de los fieles de hacer romerías, procesiones y demás manifestaciones religiosas para aplacar la ira divina y evitar así los castigos de Dios en forma de epidemias o sequías causantes del hambre y de la pobreza. Y explica, además, la proclamación de Vírgenes como patronas de villas y ciudades con la función de "abogadas contra la peste", etc. y según la Teología cristiana, para interceder ante Dios en favor de los hombres, y evitar así sus castigos. Esto se puede comprobar en cada uno de los casos concretos de apariciones o proclamaciones de Patronas y Patronos de las ciudades (Christian 1972, 1975: 2205-2207, 1976, 1978, 1981a y 1981b; Maldonado 1990: 72-73). Lo ocurrido en Villena es un ejemplo representativo de este fenómeno tan generalizado en la Edad Moderna. Nuestra Señora de las Virtudes fue proclamada Patrona de Villena y Abogada contra la Peste, según la leyenda, en 1474 junto a la Fuente del Chopo, donde se levantó el Santuario que hoy conocemos. Esta leyenda se basó en el relato de la aparición de la Virgen que hizo el prior del convento fray Mateo García en 1722, es decir, 248 años después de haber ocurrido los supuestos hechos. Después, se narró en la segunda parte de la Comedia de Rodrigo Gabaldón, editada en Villena en 1757 (Domene 2013: 121-131; Prieto y Domene 2014), y en 1760, solo tres años después, lo narró el médico villenense Francisco Cerdán en un libro de medicina $^{11}$ dedicado a la Patrona de Villena $^{12}$ (Domene 2013: 123-124).

era ofendido, había de ser persuadido, mediante actos penitenciales, para que no las castigara. Pero penitencia y persuasión se entendían mejor canalizadas a través de intermediarios como la Virgen y el santo. Ambos se vinculaban a la comunidad local como mensajeros benévolos que les informaban de las alternativas que tenían para evitar los castigos y que intercedían activamente ante Dios por ellos" (Maldonado 1990: 72-73).

${ }^{11}$ El título completo del libro es Disertación physico-médica de las virtudes medicinales, uso y abuso de las aguas thermales de la villa de Archena, reyno de Murcia, comunicada a la Real Sociedad Médica de Nuestra Señora de la Esperanza, de la Corte y Villa de Madrid.

12 "Por los años de 1474, se hallaba esta Nobilísima Ciudad oprimida con el feraz contagio de la peste; los clamores a la piedad divina eran infinitos; los tristes espectáculos movían a compasión a el corazón más empedernido; ayrado se manifestaba nuestro Redemptor; no se encontraban medios para aplacarle: propagábasse el contagio con la mayor actividad; flaquearon en un todo los humanos remedios y, ausentándose los sanos de los apestados, se refugiaron como a una legua de distancia, en la fuente que llaman de el Chopo: juntáronse el Governador y demás Jueces de esta República; y como no se encuentran medios más proporcionados para aplacar la Divina Justicia que la penitencia y la intercesión de los santos, determinaron edificar en aquel sitio una Hermita a donde se tributasse culto a el Santo que se eligiesse y nombrasse por Patrono de esta ciudad. No se conformaron, pues cada uno quería elegir el suyo, y a el que mayor devoción tenía; resuelven (para evitar questiones) colocar a el que por suerte le cupiesse; y para este fin pusieron en un cántaro las cédulas con el nombre que su devoción a cada uno le dictó: qual a el Señor san Sebastián, qual el Señor san Gil, etc. Puestas las cédulas en el cántaro, mandaron las fuesse sacando un niño; pero iprodigio maravilloso! En la primera cédula que sacó, se hallaron buriladas las siguientes palabras: MARÍA DE LAS VIRTUDES. Confusos se preguntaban unos a otros quién havía puesto semejante cédula, y todos testificaron no haver escrito tal nombre: rásganse todas, repítesse hasta tercera vez y hasta ésta respondió el prodigio. Jubilosos con tan soberano milagro, nombran comissarios para que, con la mayor brevedad, manden executar una Imagen a quien se le dé el título de Nuestra Señora de las Virtudes. Salen presurosos a cumplir su legacía, y a muy poca distancia, encuentran dos preciosísimos mancebos, los que en una caxa traían la verdadera Imagen que oy en esta ciudad veneramos, de Nuestra Señora de las Virtudes; con el mayor regocijo, manifiestan el sagrado relicario y salen a buscar los conductores 
En 1884, lo narra con bastante exactitud José Zapater Ugeda (1884: 25-36). Comienza cuando en 1474 (según la leyenda) los ciudadanos de Villena, huyendo de la peste, levantaron barracas y chozas en la Fuente del Chopo. Como la peste continuaba también allí, decidieron la elección de un santo por patrono de la ciudad que los protegiera de ella. La aparición de la imagen de la Virgen de las Virtudes ocurrió, también según la leyenda, unos días después de su proclamación, y fue traída por dos mancebos que al final resultaron ser ángeles. Sin embargo, según los datos históricos de los que disponemos, este hecho habría tenido lugar en septiembre de 1476, dos años después de la fecha tradicional, y tras la rebelión de los cristianos viejos de la villa contra el Marqués de Villena (Pretel 1999: 32), porque en 1474 no hubo ninguna epidemia de peste, sino dos años después, en 1476, y fue en el mes de septiembre de ese año cuando se produjo (Domene 2000).

En la religiosidad popular, el objeto de devoción y de culto no es el personaje de la Virgen o del santo, representado por una talla o imagen esculpida en madera o yeso, sino la misma talla o imagen esculpida en madera o yeso. Por lo tanto, el objeto de culto no es el santo o la Virgen sino su representación iconográfica, que además se convertía en un símbolo identitario de la localidad. De nuevo se comprueba que la religiosidad popular es, por tanto, concreta y material, y carente de cualquier idea abstracta. El culto a la representación iconográfica de la Virgen se puede comprobar en algunas obras literarias del siglo XVIII como las Comedias marianas de Rodrigo Gabaldón (Prieto y Domene 2014: 41-42) ${ }^{13}$.

\section{LAS FIESTAS PATRONALES COMO MANIFESTACIÓN DE LA IDENTIDAD LOCAL}

La principal función social que tienen las fiestas patronales es, desde el punto de

para darles el justo pago; pero, ió repetición del prodigio!, ya estos se havían desaparecido. ¿No es a la verdad el mayor portento y assombro que puede encontrarse? ¿Socorrernos y favorecernos sin llamarla ni invocarla? ¿Pues no hay tradición de que se pusiera cédula alguna de María Santísima con este ni con otro título?» (Domene 2013: 123-124).

${ }_{13}$ "Hay otro aspecto en relación con la Virgen que requiere atención, en tanto que signo de identidad católica en oposición frontal a las enseñanzas luteranas. Tiene que ver no ya con el culto a María, sino con el que se prodiga a su imagen (término este, el de "imagen", que aparece sistemáticamente escrito con inicial mayúscula en la edición de 1757). Ello es bien visible en el encabezamiento de la primera dedicatoria, donde se habla de "su santísima y prodigiosa imagen"; sirva a modo de ejemplo, con numerosas réplicas en el texto de ambas comedias. Determinadas actuaciones y expresiones de los personajes evidencian un desplazamiento del culto de la Virgen al de su representación iconográfica. Nótese la importancia que el gobernador, como representante real, concede a la consecución de la imagen de la nueva patrona, y el que sean dos ángeles en forma humana quienes aportan la imagen encerrada al efecto en una urna (en este sentido, la aparición milagrosa o inexplicada de la imagen recibe el mismo tratamiento que una aparición mariana). Y aunque puede parecer paradójico, a idéntica conclusión conducen las imprecaciones de Lucifer contra dicha imagen, causa de sus fracasos y a la que se refiere ofensivamente como "tronco rústico", "inanimado leño", "tosco leño"... No cabe ignorar, en fin, que la utilización de imágenes sagradas era reprobada por los reformadores luteranos, y que el contrarreformismo católico puso en ello un énfasis especial como afirmación de la especificidad dogmática del catolicismo frente a creencias sospechosas de heterodoxia, y también como apoyo didáctico que contrarrestaba sensorialmente la sequedad de las abstrusas razones teológicas" (Prieto y Domene 2014: 41-42). 
vista etic, la identitaria, ya que son vividas inconscientemente por los habitantes de cada localidad como un signo de identidad de la misma (Moreno y Agudo 2012: 178182), de manera que el santo o la Virgen, y su respectiva imagen escultórica o representación iconográfica, constituyen en realidad un símbolo que la caracteriza y la distingue de otras localidades vecinas. Los estudios sobre las fiestas locales y generales consideran su carácter identitario ${ }^{14}$ y hacen referencia a las fiestas como "afirmación de la identidad local». Esto se puede demostrar claramente porque hay dos hechos que lo confirmarían.

En primer lugar, la gente tiene devoción al santo o a la Virgen que es el Patrón o la Patrona de su localidad, pero no a los de otras localidades, hasta el punto de que estos últimos pueden ser intrascendentes para los habitantes de otras localidades ${ }^{15}$.

${ }_{14}^{14}$ "Un aspecto fundamental de las fiestas es el papel que juegan como rituales para la reproducción de identidades. Si esto es evidente en la mayoría de las fiestas que se llevan a cabo a nivel comunal, todavía queda más palpable en las fiestas patronales, o ligadas al componente religioso, y realizadas en honor de un patrón o patrona de la localidad en cuestión. Se trata de unas fiestas cuyo elemento principal descansa en la identificación de las personas y de los grupos. No obstante, esto es posible gracias a la presencia del grupo total (nosotros, los de dentro, y ellos, los de fuera) y la presencia de lo sagrado. Identificarse significa, entonces, potenciar lo propio frente a los otros. Sin embargo, a pesar de las posibles desavenencias que puedan deparar dichas festividades, el ritual se encarga de afirmar la identidad y la unión de la comunidad. En los momentos festivos, los individuos tienden a resaltar la pertenencia a su pueblo utilizando a las imágenes religiosas locales como símbolos que perpetúan la integración de la comunidad" (Castilla 1999: 155).

${ }^{15}$ Los ejemplos existen en todos los países católicos, y en ellos en todas las regiones y en todas las comarcas. Por citar solo algunos ejemplos, en la localidad alicantina de Sax se tiene devoción a san Blas, porque se le atribuye la erradicación de una epidemia de difteria en 1647, pero san Bonifacio Mártir, que es el Patrón de la localidad vecina de Petrer, o san Antón, que lo es de la localidad también vecina de Elda, les resulta intrascendente a los sajeños. El caso más evidente es el de la Virgen, que siendo siempre la misma, aunque adopte distintos nombres, en cada localidad se venera únicamente a la que es Patrona de esa localidad, y no a las Vírgenes que son patronas de las demás localidades. Y lo mismo ocurre con su representación iconográfica, que llega a identificar a los habitantes de la localidad de la que es Patrona. Así, por ejemplo, los habitantes de Villena tienen devoción a la Virgen de las Virtudes, pero la Virgen de Gracia, que es la Patrona de los pueblos vecinos de Caudete y Biar, o Virgen de la Soledad, que es la Patrona de Castalla, por ejemplo, les son intrascendentes a los habitantes de Villena. Como resulta evidente, la devoción popular no es a la Virgen María, madre de Jesucristo, sino a la Virgen de las Virtudes, Patrona de Villena, porque se le atribuye que acabara con la epidemia de peste en 1474, según la leyenda, y en 1476, según los datos históricos. Pero los habitantes de Villena, además, a quien tienen devoción es a la talla de la Virgen de las Virtudes, realizada en 1939 por el escultor Antonio Navarro Santafé para sustituir a la talla original que habían quemado en julio de 1936. Otros santos o Vírgenes, patronos o patronas de ciudades especialmente importantes, han funcionado como signos de identidad regional o incluso nacional. Basta recordar ejemplos significativos como el apóstol Santiago, verdadero símbolo de identidad de Galicia, e incluso de España; la Virgen del Pilar, símbolo de identidad de Aragón, de España y de la Guardia Civil; la Virgen del Rocío, símbolo de identidad de Andalucía; la Virgen de Montserrat, de Cataluña; la Mare de Dèu dels Desamparats ( LLa Geperudeta), de Valencia; N. ‥ S. de Arantzazu, de Guipúzcoa; etc. Lo mismo ocurre en otras fiestas religiosas distintas de las patronales, como por ejemplo, la Semana Santa. Es sobradamente conocido el carácter identitario de las Vírgenes y los Cristos de la Semana Santa sevillana en los barrios de la ciudad (la Macarena, Triana, el Cristo de los Gitanos, etc.); o el carácter identitario de grupo. Es paradigmático el carácter de identidad de grupo, incluso competitivo, que tienen las dos Vírgenes de la Semana Santa de Lorca, la Virgen de la Amargura y la Virgen de los Dolores, y la rivalidad entre las dos cofradías respectivas, los blancos y los azules. Esa identidad, rivalidad y 
Pero, no solo son las imágenes las portadoras de la identidad local, sino también los mitos de origen de cada advocación ${ }^{16}$ (Velasco 1989, 1996, 1999, 2000; Delgado 1992).

En segundo lugar, el santo o la Virgen que es el Patrón o la Patrona de una localidad es objeto de devoción de casi la totalidad de sus habitantes, sean creyentes o no. Lo natural sería pensar que los devotos al Patrón o la Patrona de una localidad fueran solo los creyentes, pero sorprende ver cómo hay muchos vecinos que, aun siendo creyentes, no practican su religión ni van a misa en todo el año, pero sí van a ver a la Virgen o al santo patrón durante los días de fiestas y participan en los actos religiosos que se celebran en su honor. Pero es que los agnósticos y ateos también tienen devoción al Patrón o a la Patrona de su localidad, igual que los creyentes. Es representativa la frase que dijo un ateo y de izquierdas durante la Guerra Civil española: "Yo soy ateo, pero a la Virgen de las Virtudes que no me la toque nadie». Evidentemente, los ateos que actúan así, no tienen devoción a un santo determinado del santoral católico, ni a la Virgen María, madre de Jesucristo, sino al Patrón o a la Patrona de su localidad como signo de identidad local, reforzado por las atribuciones milagrosas que se le han atribuido a lo largo de la historia local. El hecho de ser considerado como benefactor de los habitantes de la localidad frente a las enfermedades, epidemias y otras catástrofes naturales como las sequías, y al cual se han dirigido sus habitantes a lo largo de varios siglos para pedirle que les devolviera la salud o para que trajera la lluvia, ha hecho que sea considerado como un icono benefactor y sanador de los habitantes de esa localidad. El procedimiento es el mismo que el de los pueblos primitivos que bailaban la danza de la lluvia para que las divinidades animistas (el dios del trueno, la diosa nube o la diosa lluvia, por ejemplo) favorecieran al pueblo que los invocaba. Pero, además, tales favores se los tienen que pedir al santo-patrón o a la Virgen-Patrona de su localidad, y no a otra, porque la suya es la más milagrosa y la que más les puede favorecer en sus peticiones. Algo similar ocurre en otras fiestas religiosas distintas de las patronales, como la Semana Santa. La devoción a las Vírgenes y los Cristos de la Semana Santa sevillana (la Macarena, Triana, el Cristo de los Gitanos, etc.) o la de Lorca, por ejemplo, en las que los cofrades son tanto creyentes como no creyentes, y estos últimos participan en las cofradías tanto como aquellos ${ }^{17}$.

apasionamiento son comparables a los sentimientos identitarios de fenómenos sociales contemporáneos como el fútbol, con la clásica rivalidad entre el Real Madrid y el Barça, o la política, entre los dos partidos mayoritarios, el PP y el PSOE.

16 "La importancia de los santuarios con advocaciones marianas debemos conectarla con la matrifocalidad propia de la cultura andaluza, con el papel central en Andalucía de la mujer-madre, que es simbolizada en la Virgen-Madre. De aquí su preponderancia en la religiosidad popular, como intercesora maternal ante la divinidad, frente a la especificidad protectora de los santos/santas. Pero también es preciso reseñar la recurrencia a estas advocaciones para marcar las diferencias localistas entre unos pueblos y otros: no sólo van a particularizarse por la especificidad de sus advocaciones respecto a imágenes de similar simbología veneradas en los pueblos vecinos (Rocío, Cabeza, Luna, Alcantarilla, Guaditoca, Setefilla, Guía, Antigua, Piedrasantas, Flores, Blanca, Mar, Victoria, Cinta, etc.), sino que con los mitos de origen que justifican sus hallazgos/apariciones y la razón de la ubicación de sus santuarios se afirma la legitimidad del vínculo especial, inequívoco y excluyente, de cada comunidad con esta y no otra imagen" (Moreno y Agudo 2012: 191-192).

17 "Más que un fenómeno perteneciente al ámbito religioso, y sin negar este componente, la celebración aparece hoy estrechamente ligada al ámbito identitario, al autorreconocimiento individual y colectivo. De ahí que la posición de cada persona concreta respecto a las creencias y 


\section{LAS FIESTAS PATRONALES COMO INSTRUMENTO DE DOMINACIÓN SOCIAL}

Pero la religiosidad popular, además, ha tenido en la historia una función social muy importante para el mantenimiento del orden social establecido, especialmente en la sociedad feudal y en el Antiguo Régimen en general, ya que ha sido el instrumento ideológico que ha asegurado la sumisión a los señores feudales y a la monarquía, así como el cobro de las rentas y de los diezmos por parte de la Iglesia, de los señores feudales y de la nobleza en general: "Las fiestas patronales son, en alguna medida, la manifestación de la sumisión a un nuevo señor, no ya feudal, que los domina, sino al santo que los protege, pero de algún modo el santo es el señor del pueblo, la Iglesia domina al pueblo a través de sus santos" (Sánchez 1978: 261-266). Y la Iglesia también aprovechaba las fiestas patronales para demostrar su poder: "Algunas fiestas o algunos de sus elementos son una copia de las grandes fiestas políticas celebradas durante la Baja Edad Media en las que la Iglesia intentó dar a conocer o manifestar toda su fuerza y poder. Pertenecen a este grupo de fiestas las patronales que se celebran en todas las ciudades, villas y aldeas, las fiestas de cofradías y, especialmente, el Corpus Christi” (Sánchez 1978: 261-266).

Con los cuantiosos beneficios que obtenía la iglesia, procedentes del cobro de los diversos impuestos eclesiásticos (diezmo, primicia, barchilla, etc.), se construían las catedrales, los palacios episcopales, etc.; además servían para el mantenimiento del clero sin ningún tipo de privaciones. El alto nivel de vida que mantenía el clero propietario de las tierras y beneficiario de las rentas y los impuestos eclesiásticos, contrastaba con la miseria y la penuria que padecía el campesinado arrendatario de esas tierras, que era el que tenía que pagar las rentas y los impuestos eclesiásticos ${ }^{18}$. Y lo mismo ocurría con los señores feudales y con la monarquía, que también mantenían su alto nivel de vida a costa de las rentas que les pagaban sus vasallos.

Y de aquí surge una pregunta: ¿cómo conseguían la Iglesia, los señores feudales y la monarquía que los campesinos les pagaran puntualmente el diezmo y las rentas feudales? Para ello disponían de dos medios coercitivos y disuasorios. Por una parte, las leyes civiles, que penaban el impago del diezmo y de las rentas feudales, y por otra la Inquisición, que perseguía, juzgaba y condenaba a los que no pagaban. Por otra, un medio que no es ni económico ni jurídico, sino ideológico, como es la misma religión, en este caso la católica, ya que los que no pagaban el diezmo se harían merecedores del castigo divino, y ese castigo divino lo sufrirían, no solo en la otra vida, después de la muerte, yendo al infierno eternamente, sino también en esta, mediante catástrofes naturales como epidemias y sequías, que Dios enviaba para castigar los pecados de los hombres, uno de ellos el impago de los diezmos que ya fi-

\footnotetext{
observancias religiosas no sea un indicador adecuado para conocer su participación o no en estos rituales. Y lo mismo podríamos decir respecto a la mayor parte de las romerías, fiestas patronales y otras celebraciones a lo largo y ancho de la Península" (Moreno 1999: 20).

18 "De todas formas, es evidente que la Iglesia española era riquísima y que, considerada globalmente, tenía un sobrante considerable que se canalizaba en tres direcciones principales: limosnas, incremento del patrimonio artístico y nuevas adquisiciones inmobiliarias; este último aspecto es importante, porque revela el fundamento de la creciente hostilidad de la clase campesina. En el siglo XVIII los monasterios ya no recibían donaciones inmobiliarias, pero seguían acrecentando su patrimonio merced al sobrante de sus rentas" (Domínguez 1976: 362).
} 
gura en las Partidas (Ley 21, Título 20, libro 1ㅇ): "E desto fablo Malachias profeta, en presencia de Nuestro Señor Dios, e dixo assi: porque no me distes los diezmos por eso soys maldito en fambre e en pobreza...". Esto confirma que la religión - perteneciente a la estructura ideológica de la sociedad- es el elemento que hace posible la sociedad feudal y, sin el cual, esta no podría existir. De ahí que, en el feudalismo, la estructura ideológica sea considerada como la dominante de la sociedad ${ }^{19}$ (Artola 1991: 112). Esta función social que tiene la religiosidad popular $-\mathrm{y}$ la religión en generalde mantener el orden social establecido, se comprende muy bien, desde el punto de vista etic, a partir de algunas de las características de las fiestas patronales y, sobre todo, de este tipo de fiestas en la antigüedad.

A la Virgen-Patrona de muchas localidades se le denominaba hasta hace un siglo «la Señora" y, en la actualidad, sigue estando generalizado el uso de "Nuestra Señora" para referirse a la Virgen-Patrona de alguna localidad (Nuestra Señora de las Virtudes, Nuestra Señora de Gracia, etc.), de forma paralela al "Señor", que es como siempre se ha denominado a Dios y a Jesucristo ("Dios Nuestro Señor" o "Jesucristo Nuestro Señor"). En latín, DOMǏNus, para referirse a Dios y a Jesucristo, y DomǏNA, para referirse a su madre, la Virgen María, tenían el mismo significado que "Señor" y "Señora" y, naturalmente, mayor antigüedad. Pero estas denominaciones de DoMǏNus-Señor y DOMĬNA-Señora mantenían un perfecto paralelismo con el "señor" feudal y con la "señora", es decir, con la esposa del señor feudal. Mediante ese paralelismo léxico, se equiparaba a unos con otros y a las virtudes y cualidades de unos con las de los otros. Es decir, se equiparaba al señor feudal, a quien todos sus vasallos debían pagar los impuestos o rentas feudales, con el "Señor", Dios-Padre, el creador del mundo, y con "Nuestro Señor" Jesucristo, su hijo, que según la religión cristiana, murió por todos nosotros para redimirnos del pecado original. El señor feudal se veía así revestido, inconscientemente, de todos los atributos de Dios, que además, según la religión cristiana, es nuestro "Padre" porque nos creó a su imagen y semejanza el sexto día de la creación. Tomás de Aquino ya estableció los atributos o cualidades de Dios en la Summa Theologica. Entre esas cualidades atribuidas por Tomás de Aquino, o atributos divinos, Dios era perfecto, bueno, justo, misericordioso, etc., y todo ello en grado sumo, es decir, era la "bondad suma", la "perfección suma", etc., además de ser todopoderoso (omnipotente o pantocrátor). Esas cualidades atribuidas a Dios por la Escolástica, se le atribuían por tanto indirecta e inconscientemente a los señores feudales y a sus esposas, que además se mostraban de forma paternalista

\footnotetext{
19 "La sociedad del Antiguo Régimen, sometida a la autoridad de monarcas absolutos, disfrutó de una estabilidad que solo interrumpen revueltas de gran violencia -comunidades, germanías, alteraciones de mediados del siglo XVII, motín de Esquilache- pero carentes de continuidad. En todos los casos, las exigencias fiscales de la Corona actúan como detonador y en la mayoría de ellos son seguidos por duras represiones que restablecen para largo tiempo el orden comprometido. Un indicador del bajo nivel habitual del conflicto lo constituyen los limitados efectivos de las fuerzas armadas disponibles para mantener el orden público. Como causa de esta estabilidad cabe mencionar el aislamiento en que se encuentran los diversos grupos humanos de resultas de su condición rural. La sociedad del Antiguo Régimen es una sociedad poco menos que incomunicada en el doble sentido de la transmisión de noticias y del desplazamiento de las personas. Al mismo tiempo experimenta las consecuencias de una intensa acción socializante por parte de la Iglesia, que no solo predica la salvación individual sino que, al mismo tiempo, justifica el orden establecido e interviene con especial eficacia en el control de las conductas desviadas y el castigo de los delitos de opinión" (Artola 1991: 112).
} 
con sus vasallos en la Edad Media, siguiendo el paralelismo con Dios-Padre. El pantocrátor figuraba, además, en el tímpano de las portadas románicas dentro de la mandorla místi$c a$, y era la figura central del cristianismo medieval. A esos atributos divinos había que añadir las potencias de Dios, que para Tomás de Aquino eran tres, la creación del mundo, como causa de todas las cosas, su conservación, manteniendo la existencia del mundo creado por él, y la providencia, que es la intervención de Dios y la ordenación de la vida de todas las criaturas creadas por él. Además de todo esto, Dios era el juez supremo que juzgaría a todos los mortales en el juicio final. La identificación de los señores feudales con un ser superior que tenía estas cualidades y potencias les daba un poder psicológico importantísimo ante sus vasallos. De hecho, el señor feudal tenía todos los poderes políticos, el legislativo, el ejecutivo y el judicial, porque era el que gobernaba el señorío, dictaba las leyes y juzgaba a sus vasallos. La ciencia moderna se encargaría de contradecir siglos después la metafísica tomista y, especialmente, los atributos y las potencias de Dios.

Pero Jesucristo también era el "Rey de los Judíos" y su madre, la Virgen María, ha sido considerada como la "Reina del Cielo" o la "Reina de los Cielos", por lo que, gracias al paralelismo léxico con las palabras "rey" y "reina", las monarquías (los reyes y las reinas) también se han podido asimilar, en la mente de los súbditos, a la figura de Jesucristo y a la de la Virgen María, respectivamente, e identificarlos con ellos. Al igual que los señores feudales, también los reyes tenían el poder legislativo, el ejecutivo y el judicial, porque a la vez gobernaban su reino, dictaban las leyes y juzgaban a sus súbditos, entre los cuales también se encontraban los señores feudales. El paralelismo de Dios y la Virgen con los reyes y reinas, respectivamente, es muy evidente; a la vez que el carácter de fieles y devotos a Dios y a la Virgen es también análogo al hecho de ser súbditos a un rey o a una reina; también se solapa en el inconsciente popular, de manera que había que ser un buen súbdito del rey y de la reina igual que se era ferviente devoto de Dios y de la Virgen.

La mayor y más explícita exaltación de la monarquía es, sin embargo, la fiesta de los Reyes Magos. Potenciada en su forma actual en el siglo XVIII, en pleno auge de la monarquía absoluta y la Ilustración, potencia de forma evidente el carácter bondadoso y generoso de los reyes, personificados en Melchor, Gaspar y Baltasar, y va dirigida precisamente a los niños, para educarlos desde la infancia en el amor a la monarquía. Los tres reyes magos les traen regalos a los niños, pero solo a los niños que se han portado bien durante el año, con lo cual los reyes se convierten en jueces del comportamiento que han tenido los niños durante todo el año, en un paralelismo con la función judicial que tenían los reyes (en última instancia), los nobles y los señores feudales (en segunda instancia) y los alcaldes ordinarios de Castilla (en primera instancia) en el Antiguo Régimen, función que naturalmente delegaban todos ellos en jueces profesionales. La función social de apoyo y exaltación de la monarquía y la nobleza que tenía la fiesta religiosa de los Reyes Magos se realizaba así desde la más tierna infancia.

También las cualidades y las virtudes de los santos se asociaban mentalmente con las de los señores feudales, y muchas veces eran estos últimos los que elegían a su santo predilecto como Patrón de alguna de las localidades de su señorío ${ }^{20}$.

${ }^{20}$ Es el caso, por ejemplo, de san Bonifacio Mártir, que fue elegido como patrón de Petrer por el Conde de Elda, que era el señor feudal de la localidad. En el País Vasco, por ejemplo, se 
A lo largo de la Historia, desde el punto de vista etic, el hecho de ser fiel o devoto a Dios, a un santo o a una Virgen ha sido paralelo a ser fiel y vasallo de un señor feudal o de un rey. En la Edad Media, los vasallos juraban fidelidad a su señor mediante el ritual del juramento de fidelidad y el pacto de vasallaje, que establecían jurídicamente las relaciones feudales de dependencia entre el señor y sus vasallos. Era la ceremonia del homenatium u "homenaje", que se realizaba en la "torre del homenaje" de los castillos, y en ella el rey o el señor feudal aceptaba el homenaje y la fidelidad de sus vasallos mediante la inmixtio manum. De esta manera, el señor cedía a sus vasallos un trozo de tierra para que la cultivaran y se comprometía a defenderlos en la guerra y, por otra parte, los vasallos, que no eran nobles, se comprometían a pagarle una renta anual al señor, al principio en forma de trabajo personal y más tarde en especie (una parte estipulada de la cosecha de cada año), y a participar en la guerra formando parte de la mesnada del señor (bueste y cabalgada), a hospedarlo y alimentarlo cuando pasara por su lugar de residencia, y a otras muchas obligaciones inherentes al vasallaje.

Pero estas instituciones feudales tienen su antecedente en las instituciones romanas del FCEDUS y la FİDES, es decir, el pacto y la fidelidad, que ya existían en las sociedades prerromanas de la Península Ibérica, conocidas como la DEvOTIO y la clientela $^{21}$. La misma palabra que designaba aquel tipo de pactos de fidelidad fue luego utilizada por el cristianismo para designar la relación de dependencia de los cristianos con Dios, la Virgen y los santos, esto es, la devoción, que tenía lugar entre los fieles (en latín, FIDĒLES, de FĪDES) y el Señor (es decir, el DOMǏNuS). Y el concepto de la FîDES romana ha permanecido en la fides feudal medieval y, naturalmente, en la fe cristiana. Pero no solo ha asimilado el cristianismo estos términos y estos conceptos civiles romanos, sino también otros como el del patronato $^{22}$, que se revitalizó tras la

utilizaban las palabras latinas DomǏnus y DomǏNA para denominar también a los santos y en euskera dieron lugar, respectivamente, a los prefijos don- y dona- que preceden a los nombres de los santos y de las santas (por ejemplo, Donibane es san Juan, Doneztebe es san Esteban, etc.).

${ }^{21}$ Los romanos "supieron, sobre todo, utilizar aquellos elementos institucionales que representaban un factor de desintegración dentro de las sociedades indígenas, como los pactos personales con los jefes de los pueblos: Escipión con Indíbil, y los pactos de clientela y devotio que unían a los indígenas de forma personal con los generales romanos y deshacían, por consiguiente, la cohesión de los grupos gentilicios" (Vigil 1985: 284). En efecto, "las desigualdades sociales surgidas entre esos pueblos hacían que los miembros de ellos, carentes de recursos, se agruparan alrededor de un jefe que les aseguraba los medios de vida. Los romanos aprovecharon en su favor estos pactos personales para minar la resistencia que les pudieran oponer los pueblos indígenas, agrupando los generales romanos, alrededor de su persona, a numerosos indígenas por medio de la clientela y la devotio. Estas relaciones de dependencia se expresaban también por medio del concepto de fidelidad o fides" (Vigil 1985: 263).

22 "Las relaciones entre los grandes propietarios y el campesinado se desarrollaron dentro de una antigua institución romana, el patronato o patrocinio, que adquiere un nuevo contenido. El régimen de patronato permitía al señor territorial tener una relación de tipo personal con sus colonos y los trabajadores de sus fincas, a los que podía sustraer de las obligaciones que como campesinos libres tenían con el Estado romano respecto al fisco y al ejército. Los grandes propietarios contaban incluso con ejércitos propios compuestos por sus campesinos (...). Por consiguiente, se llegó a una situación pre-feudal o de feudalismo primitivo, sin que se pueda hablar de una sociedad feudal en el Bajo Imperio, ya que las nuevas relaciones no alcanzaron todavía a la constitución general del Estado y a las normas político-jurídicas generales, que seguían basándose en las instituciones del Alto Imperio, las únicas que podían mantener la existencia de un Estado centralizado" (Vigil 1985: 386). 
crisis del siglo III d.C. y como consecuencia de la nueva situación social surgida entonces: el colonato ${ }^{23}$. El patronato romano también fue asimilado por el cristianismo y se ha mantenido en el aspecto religioso hasta nuestros días en la figura del patrón o de la patrona de una localidad, siendo estos los santos, las santas y las Vírgenes proclamadas por las ciudades y villas, así como por los gremios del Antiguo Régimen. Por lo tanto, el paralelismo entre los patronos latifundistas o grandes propietarios del Bajo Imperio romano con los patronos y patronas de carácter religioso de las ciudades y de los gremios en la Edad Media y la Edad Moderna es también muy evidente.

El paralelismo entre los señores feudales, por una parte, y "Dios Nuestro Señor", la Virgen ("Nuestra Señora") y los santos y santas, por otra, explica y permite comprender, desde el punto de vista etic, las características y las vivencias populares de las fiestas religiosas y patronales, dentro de lo que se denomina religiosidad popular. Es el caso, por ejemplo, de la indumentaria con la que se viste a las imágenes de los santos y, sobre todo, a las de las Vírgenes que procesionan en las fiestas católicas. El lujo y la decoración de esas vestimentas, que con frecuencia consisten en mantos muy costosos, bordados en oro y plata, es paralelo al lujo de las vestimentas de la nobleza y de la realeza en la Edad Media y en la Edad Moderna, y solo se explica si se tiene en cuenta ese paralelismo, ya que a la Virgen se la tiene que vestir como a una reina porque es la "Reina de los Cielos". Puede sorprender que, en una sociedad con un alto nivel de pobreza y en la que una parte mayoritaria de la población tenía tal escasez de recursos que apenas le permitía la subsistencia, se consintiera ese lujo y ese despilfarro en la vestimenta de la imagen de la Virgen o de los santos, así como en la decoración de los tronos o pasos sobre los que procesionan, que suelen estar tallados en madera y llevan multitud de velas y cirios para su iluminación, además de otros muchos adornos. No es por casualidad que los pasos en los que procesionan las imágenes religiosas se denominen, en muchos lugares, "tronos", y como tales se conciben en todas partes. Son los tronos que llevan al "Rey de los Judíos" o a la "Reina de los Cielos". Una vez más, surge el paralelismo con señores feudales y, en la sociedad contemporánea, con los latifundistas y terratenientes, tan característicos de Andalucía, Extremadura, Castilla-La Mancha y, en menor medida, de Castilla-León, Galicia y la mayor parte de Murcia, que son precisamente $-\mathrm{y}$ no por casualidadlas regiones en las que la Semana Santa se vive con mayor intensidad.

El paralelismo no solo existe entre los señores feudales y "Dios Nuestro Señor" o la Virgen ("Nuestra Señora"), sino también entre los vasallos y los devotos, que en las fiestas religiosas y patronales reproducen las mismas relaciones sociales que tienen con sus señores y amos. Esto se puede ver, literalmente hablando, en las procesiones, en las que los costaleros llevan sobre sus hombros los pasos o "tronos" sobre los cuales se coloca la imagen del santo, del Cristo o de la Virgen. Es decir, es el pueblo llano el que lleva sobre sus hombros el peso de los pasos con la imagen del Señor o de la Virgen ("Nuestra Señora"), con el esfuerzo físico y el consiguiente sufrimiento que eso conlleva.

\footnotetext{
23 "La aristocracia local de las regiones no demasiado romanizadas pudo convertirse ante la nueva situación en una clase de grandes propietarios territoriales, quedándose con las tierras que habían sido antiguamente posesión de la comunidad. En estos territorios la población campesina quedaría sometida al régimen de colonato, según la legislación romana entonces vigente» (Vigil 1985: 386).
} 
El paralelismo con la sociedad tradicional es perfecto, ya que en el mundo rural los campesinos, para poder alimentarse, tenían que trabajar las tierras del señor feudal, del noble, del terrateniente o del latifundista, pero también debían pagarle las rentas de las tierras que cultivaban. Tenían que "ganarse el pan con el sudor de su frente", para su propia subsistencia, pero también para enriquecer a su señor feudal, que era el dueño de la tierra, y para que este pudiera mantener el nivel de vida, el lujo y el despilfarro propios de su condición nobiliaria.

En las fiestas patronales, y en la Semana Santa sobre todo, los costaleros tienen que soportar el peso de los pasos sobre los que está el Señor (Dios) o "Nuestra Señora" (la Virgen), y tienen que padecer los dolores de espalda, el sudor y la fatiga de ese ingente esfuerzo físico que realizan por Él o por Ella. El paralelismo con los campesinos en Andalucía y otras regiones españolas, que tienen que padecer por trabajar las tierras de su señor feudal, terrateniente o latifundista, es perfecto y, por ello, se puede afirmar que las fiestas religiosas legitiman y afianzan de forma evidente las relaciones sociales de sumisión a los terratenientes y latifundistas del campesinado andaluz y de la España meridional en general, que se caracteriza por tener un elevado porcentaje de jornaleros. El pueblo llano y trabajador se identifica, así, con el Cristo que sufre llevando la cruz hacia el Calvario, y que luego es crucificado allí por los romanos. Las fiestas religiosas, por tanto, ayudan a que los campesinos acepten la sumisión a los terratenientes y, con ello, contribuyen a mantener el orden social establecido y lo garantizan, evitando, de forma pacífica y sin llegar a utilizar métodos represivos (policía, Guardia Civil, etc.), cualquier protesta, rebeldía o intento de subversión contra ese mismo orden social que beneficia a los terratenientes en detrimento del campesinado. La religión, y más concretamente la religiosidad popular, es el instrumento ideológico que hace posible esta sumisión del pueblo llano y trabajador hacia la clase dominante, terrateniente y latifundista ${ }^{24}$. Se consigue así una sumisión pacífica de los pobres frente a los ricos mediante el concepto de alienación (tanto social como política), no solo en el Antiguo Régimen, sino también en la sociedad contemporánea y democrática, en la que se consigue que los devotos y cofrades, aunque sean obreros, agricultores o jornaleros, voten a los partidos políticos que representan a la clase terrateniente y defienden los intereses de la burguesía agraria y de los aristócratas. No es por casualidad que este fenómeno festivo-religioso se dé, principalmente, en las regiones españolas con una economía eminentemente agrícola y una sociedad rural predominante.

La aceptación de la pobreza y de la injusticia por los pobres y por los perseguidos, así como la resignación de estos prometiéndoles una recompensa en el cielo (es decir, después de la muerte), son las ideas que están en la base de la dominación social de los ricos sobre los pobres y ya están expuestas y fomentadas en los evangelios, en especial en el "Sermón de la Montaña" (Mateo 5, 1-12; Lucas 6, 20-26) de una forma muy explícita ${ }^{25}$. Después de fomentar la resignación y la sumisión de los po-

\footnotetext{
${ }^{24}$ La doctrina tradicional de la Iglesia consistía, por una parte, en que "la propiedad privada, especialmente la inmobiliaria, es un "derecho natural", que no se puede violar ni siquiera con fuertes impuestos" y, por otra, en que "los pobres deben contentarse con su suerte, pues la desigualdad de clases y la distribución de las riquezas son disposiciones de Dios y sería impío tratar de eliminarlas" (Gramsci 2010: 23).

25 "Bienaventurados los pobres de espíritu, porque de ellos es el reino de los cielos. Bienaventurados los mansos y humildes, porque ellos poseerán la tierra. Bienaventurados los que lloran,
} 
bres a los poderosos, se defiende el respeto y la obediencia a las leyes promovidas por estos últimos y se condena a los que protesten o fomenten revueltas sociales, es decir, a los revolucionarios (Mateo 5, 17-19; Romanos 13, 1-2; Efesios 6, 5-7; 1 Timoteo 6, 1; Tito 3, 1-2). Esto se dice explícitamente en el evangelio de san $\mathrm{Mateo}^{26}$ y san Pablo insiste en este aspecto, justificando el origen divino de todas las autoridades y condenando cualquier resistencia hacia ellas en las cartas a los Romanos, a los Efesios, a Timoteo y a Tito $^{27}$. Pero la sumisión total a los demás la expone san Mateo de forma muy explícita ${ }^{28}$. La religión cristiana, basada en los Evangelios, ha sido por tanto un instrumento muy efectivo para evitar las protestas sociales contra las injusticias de los poderosos, y por tanto para mantener el orden social establecido. La doctrina de la Iglesia ${ }^{29}$ hacia los pobres y los perseguidos ha seguido siempre esta línea evangéli-

porque ellos serán consolados. Bienaventurados los que tienen hambre y sed de justicia, porque ellos serán saciados. Bienaventurados los misericordiosos, porque ellos alcanzarán la misericordia. Bienaventurados los que tienen puro su corazón, porque ellos verán a Dios. Bienaventurados los pacíficos, porque ellos serán llamados hijos de Dios. Bienaventurados los perseguidos por la justicia, porque de ellos es el reino de los cielos. Dichosos seréis cuando los hombres por mi causa os maldijeren y os persiguieren, y dijeren con mentiras toda suerte de mal contra vosotros. Alegraos entonces y regocijaos, porque es muy grande la recompensa que os aguarda en el cielo. Del mismo modo persiguieron a los profetas que ha habido antes de vosotros".

${ }^{26}$ "No penséis que yo he venido a destruir la doctrina de la ley ni de los profetas: no he venido a destruirla, sino a darle su cumplimiento. Que con toda verdad os digo que antes faltarán el cielo y la tierra, que deje de cumplirse perfectamente la ley, hasta una sola letra o ápice de ella. Y, así, el que violare uno de estos mandamientos, por mínimos que parezcan, y enseñare a los hombres a hacer lo mismo, será tenido por el más pequeño, esto es, por nulo en el reino de los cielos; pero el que los guardare y enseñare, ese será tenido por grande en el reino de los cielos" (Mateo 5, 17-19).

27 "Todos han de estar sometidos a las autoridades superiores, pues no hay autoridad sino bajo Dios; y las que hay, por Dios han sido establecidas, de suerte que quien resiste a la autoridad resiste a la disposición de Dios, y los que la resisten se atraen sobre sí la condenación" (Romanos 13, 1-2). Además, los siervos debían obedecer a sus amos como si obedecieran a Dios, confirmando, por una parte, la sumisión a sus amos y, por otra, el paralelismo entre los amos y Dios: "Siervos, obedeced a vuestros amos según la carne, como a Cristo, con temor y temblor, en la sencillez de vuestro corazón; no sirviendo al ojo, como buscando agradar al hombre, sino como siervos de Cristo, que cumplen de corazón la voluntad de Dios; sirviendo con buena voluntad, como quien sirve al Señor y no al hombre" (Efesios 6, 5-7). "Los siervos que están bajo el yugo de la servidumbre tengan a sus amos por acreedores a todo honor, para que no sea deshonrado el nombre de Dios ni su doctrina" (1 Timoteo 6, 1). "Recuérdales que vivan sumisos a los príncipes y a las autoridades; que las obedezcan, que estén prontos para toda obra buena; que a nadie infamen, que no sean pendencieros; que sean afables y muestren para con todos los hombres una perfecta mansedumbre" (Tito 3, 1-2).

28 "Habéis oído que se dijo: ojo por ojo y diente por diente. Yo, empero, os digo que no hagáis resistencia al agravio; antes, si alguno te hiere en la mejilla derecha, vuélvele también la izquierda; y al que quiere armarte pleito para quitarte la túnica, dale también la capa; y al que te forzare a ir cargado mil pasos, ve con él otros dos mil. Al que te pide, dale; y no tuerzas el rostro al que pretenda de ti algún préstamo. Habéis oído que fue dicho: amarás a tu prójimo y tendrás odio a tu enemigo. Yo os digo más: amad a vuestros enemigos, haced bien a los que os aborrecen y orad por los que os persiguen y calumnian, para que seáis hijos de vuestro Padre celestial, el cual hace nacer el sol sobre buenos y malos, y llover sobre justos y pecadores" (Mateo 5, 38-45).

${ }^{29}$ La doctrina tradicional de la Iglesia Católica sobre la pobreza la resumió el filósofo italiano Antonio Gramsci (1891-1937) de la siguiente manera: "Las opiniones más difundidas sobre la cuestión de la "pobreza", que resultan de las encíclicas y de otros documentos autorizados, pueden 
ca de sumisión, obediencia y resignación; y aunque, tras la aparición del movimiento obrero, la ha ido cambiando desde finales del siglo XIX y, sobre todo, tras el Concilio Vaticano $\mathrm{II}^{30}$, esa doctrina tradicional se sigue manteniendo en la religiosidad popular y en la mentalidad de los cristianos en general.

Algo similar a lo descrito sobre la Semana Santa es lo que ocurre en otras fiestas religiosas, como las de Navidad por ejemplo (Ariño y García 2006: 19-20; Ariño 2007; Ariño y Gómez 2012), en las que se celebra el nacimiento de Cristo, el Rey de los Judíos, en un pesebre. Aunque, eso sí, fue adorado por los pastores que se hallaban en las cercanías y por los tres reyes de Oriente, los Reyes Magos, que le regalaron nada menos que oro, incienso y mirra a pesar de haber nacido en la pobreza. La identificación de los pobres de la sociedad antigua con el "Niño Jesús", que también había nacido pobre, era un procedimiento muy efectivo para que los pobres se identificaran con Jesucristo, que también había nacido pobre, y aceptaran así su pobreza y el sufrimiento que esta conllevaba, y que se justificaba así porque Cristo también había sufrido y había muerto en la cruz.

\section{LA PSICOLOGÍA DE LA RELIGIÓN COMO INSTRUMENTO DE DOMINACIÓN SOCIAL}

Además de la sumisión de los siervos a los amos, de la obediencia a las autoridades, del origen divino tanto de las autoridades como de la desigualdad social, de la aceptación de la pobreza y de la identificación de los pobres con el Cristo pobre y víctima de la injusticia, para que la sumisión pacífica de los humildes a los poderosos

$\overline{\text { resumirse en estos }}$ puntos: 1) la propiedad privada, especialmente la inmobiliaria, es un "derecho natural", que no se puede violar ni siquiera con fuertes impuestos (de este principio han derivado los programas políticos de las tendencias demócrata-cristianas para la distribución de las tierras con indemnización a los campesinos pobres, y sus doctrinas financieras); 2) los pobres deben contentarse con su suerte, pues la desigualdad de clases y la distribución de las riquezas son disposiciones de Dios y sería impío tratar de eliminarlas; 3) la limosna es un deber cristiano e implica la existencia de la pobreza; 4) la cuestión social es, sobre todo, moral y religiosa, no económica, y debe ser resuelta con la caridad cristiana y con los dictámenes de la moralidad y el juicio de la religión" (Gramsci 2010: 22-23).

${ }^{30}$ Como consecuencia del auge del movimiento obrero y de la actividad de los sindicatos desde finales del siglo XIX, la Iglesia tuvo que adaptarse a la nueva situación mediante lo que se ha llamado la "doctrina social de la Iglesia", que se ha basado en diversas encíclicas desde la Rerum Novarum del papa León XIII, promulgada el 15 de mayo de 1891. Tras el Concilio Vaticano II (1962-1965), un sector de la Iglesia Católica cambió esa actitud tradicional hacia la pobreza y los pobres, sobre todo con la llamada "teología de la liberación" y la aparición de los denominados "curas obreros", que se dedicaban a ayudar a los trabajadores más pobres y a los marginados en los barrios obreros periféricos de las grandes ciudades industriales como Madrid en los años setenta y ochenta. La Hermandad Obrera de Acción Católica (HOAC) supuso un cambio de actitud hacia la clase obrera con respecto a la Acción Católica tradicional (vid. Gramsci 2010), que en cambio había seguido la doctrina tradicional de la Iglesia y había sustentado ideológicamente a los partidos de derechas (como la CEDA, Regeneración Española, etc.), en la II República, y tuvo mucha importancia en los años cuarenta y cincuenta, ya durante el franquismo. Otro sector de la Iglesia agrupado en torno al Opus Dei y otras asociaciones católicas conservadoras (Asociación de Propagandistas Católicos, Comunión y Liberación, Legionarios de Cristo, etc.) han seguido esa doctrina tradicional de la Iglesia hasta la actualidad. 
sea realmente posible mediante la religiosidad popular, todavía falta un ingrediente, ya que, además de sufrir y conformarse con su pobreza y con su sufrimiento, los pobres tienen que sentir la necesidad de sufrir por Cristo, es decir, por el "Señor", y por tanto, también por el señor feudal. Así, los que trabajan y ganan el pan con el sudor de su frente (para que otros tengan una vida llena de lujos), los que sufren las epidemias y las injusticias sociales, los campesinos y jornaleros que trabajan las tierras de los terratenientes y latifundistas, es decir, las clases populares en definitiva, tienen que sentir la necesidad de sufrir por el santo o por la santa en cuestión, por el Cristo o por su madre, la Virgen, ya que de esta manera la devoción hacia ellos se fortalece, así como el sentimiento de sumisión de los humildes (los bumiliores de la romanidad tardía o los laboratores medievales) hacia sus "señores" terrenales (los potentiores romanos o los bellatores medievales); y, de esta manera, la consiguiente relación de servidumbre entre ambos grupos sociales también se fortalece y se hace enormemente efectiva.

Los pobres, los humildes de la sociedad, debían estar convencidos de que necesitaban esforzarse y sufrir por Cristo, la Virgen y los santos, porque solo así surgiría la necesidad de querer y poder soportar el padecimiento físico y mental que conllevaba esa devoción y, paralelamente, la servidumbre terrenal hacia los poderosos. Y la religión cristiana tenía ese instrumento para convencer a la población de que tenía que sufrir. El hecho de que Cristo hubiera sufrido en la cruz, de que la Virgen hubiera sufrido por Él, y de que los santos y santas también hubieran sufrido el martirio a causa de su fe, era el ingrediente necesario para justificar el sufrimiento de los pobres y devotos ${ }^{31}$.

Todo este sentimiento culmina con una idea que es fundamental para que estos ingredientes den el fruto deseado, el sentimiento de culpa, ya que Cristo murió en la cruz por toda la humanidad, para redimirla del pecado original; porque todos los seres humanos son pecadores desde su nacimiento y porque, además, cometen pecados y ofenden a Dios a lo largo de la vida; y si no cometen ningún pecado, da lo mismo, porque lo cometieron Adán y Eva al desobedecer a Dios, y toda la humanidad heredó aquel pecado original. Este sentimiento de culpa es lo que ha convertido al cristianismo en la religión más eficaz para someter de forma pacífica a la población y conseguir su obediencia y abnegada sumisión al "señor" feudal de turno o al rey, es decir, para que los pobres acepten trabajar para beneficiar a los ricos y sufrir por ellos, por su bienestar y su riqueza. Las fiestas patronales, y especialmente la Semana Santa, representan y simbolizan todo este procedimiento perverso de sometimiento ideológico de los pobres a la clase dominante.

Pero el sentimiento de culpa no se limitaba al pecado original y a Adán y Eva, sino que estaba presente en la sociedad a lo largo de todo el año, ya que los hom-

\footnotetext{
31 "Esto es lo que explica que las imágenes de Cristo muerto, más allá de su valor artístico, que en no pocos casos es muy alto, provoquen menos respuesta devocional popular que las imágenes de Nazarenos, del Jesús agobiado y caminante, injustamente condenado, pleno de sufrimiento pero también de dignidad: un Dios-hombre en quien el pueblo oprimido podía ver reflejada su propia experiencia; un icono con el que poder hablar, porque está vivo y escucha, e incluso puede bendecir, en ocasiones, a quienes se congregan en torno a él, como todavía hoy sucede en algunos pueblos andaluces en la mañana del Viernes Santo" (Moreno y Agudo 2012: 174). (Sobre la Semana Santa, ver también Moreno 1997, 2002, 2005 y 2006).
} 
bres y las mujeres eran pecadores y Dios los castigaba por los pecados que cometían, haciéndolos padecer enfermedades, epidemias, hambrunas, pobreza, miserias e injusticias. Las epidemias de peste del final de la Edad Media, por ejemplo, eran castigos de Dios por los pecados de los hombres. Para aplacar su ira, la ira divina, había que recurrir a unos intermediarios que tuvieran una especial influencia sobre Dios, y esos mediadores eran su madre, la Virgen, o los santos, que debido a su vida ejemplar eran capaces de influir sobre $\operatorname{Dios}^{32}$. Y la forma de hacerlo era elegir un Patrón o una Patrona y celebrar romerías, procesiones, rogativas y fiestas en su honor.

Pero no todos los hombres ni toda la sociedad eran igualmente pecadores, y por tanto culpables de los castigos divinos, sino que esa culpabilidad recaía especialmente en los más pobres, ya que Dios ya los había castigado por sus pecados haciéndolos pobres. La pobreza era, por tanto, un castigo de Dios debido a la maldad de las personas que la padecían. Así, en la Edad Media, los labradores más ricos de las ciudades y villas se llamaban omes buenos, en contraposición a los más pobres, que no lo eran. Por eso, la palabra villano es despectiva en el léxico castellano. El príncipe don Juan Manuel escribió en el Libro de los Estados sobre los pecheros o villanos, diciendo que "muchos destos son menguados de entendimiento" y, lo más importante, que "son sus estados muy peligrosos para la salvación de las almas"; los consideraba, por tanto, ignorantes y pecadores, y por lo que se puede interpretar de aquí, también delincuentes, o malvados cuando menos ${ }^{33}$. $E l$ propio don Juan Manuel afirma las grandes posibilidades que tenían de condenarse eternamente los pertenecientes a este grupo" (López 1997: 77). Por lo tanto, eran los villanos, las gentes del común, los pobres, solo por serlo, los

${ }^{32}$ En Villena lo dijo de forma explícita Francisco Cerdán en 1760: "Por los años de 1474, se hallaba esta Nobilísima Ciudad oprimida con el feraz contagio de la peste; los clamores a la piedad divina eran infinitos; los tristes espectáculos movían a compasión a el corazón más empedernido; ayrado se manifestaba nuestro Redemptor; no se encontraban medios para aplacarle: propagábasse el contagio con la mayor actividad; flaquearon en un todo los humanos remedios y, ausentándose los sanos de los apestados, se refugiaron como a una legua de distancia, en la fuente que llaman de el Chopo: juntáronse el Governador y demás Jueces de esta República; y como no se encuentran medios más proporcionados para aplacar la Divina Justicia que la penitencia y la intercesión de los santos, determinaron edificar en aquel sitio una Hermita a donde se tributasse culto a el Santo que se eligiesse y nombrasse por Patrono de esta ciudad" (Domene 2013: 123-124). Se habla, por tanto, de "aplacar la Divina Justicia" mediante "la penitencia y la intercesión de los santos", y quien tiene la iniciativa y la lleva a efecto es "el Governador y demás Jueces de esta República", es decir, los miembros del concejo, que pertenecían a la élite social y económica de la ciudad.

33 "El tercer estamento, en cambio, el de los laboratores fue importante y variado. Más diversificado en las localidades grandes por su mayor capacidad económica y rango social. Aunque la función que desempeñaban constituía el auténtico fundamento que permitía el mantenimiento de todo el edificio social, eran minusvalorados e incluso vistos con desprecio. El propio don Juan Manuel afirma las grandes posibilidades que tenían de condenarse eternamente los pertenecientes a este grupo, pues muchos destos son menguados de entendimiento y son sus estados muy peligrosos para la salvación de las almas. El escalón más elevado de este grupo social lo conformaban los caballeros villanos, dueños de extensas propiedades, los ganaderos y mercaderes acomodados. En las localidades menos importantes constituían el núcleo de las élites locales con el título genérico de hombres buenos. Terminaron acaparando casi todos los cargos municipales y, con profunda insolidaridad, siempre tratarían de hacer recaer las cargas sobre los menos afortunados. La clase inferior de este estamento la constituían los menestrales de la incipiente artesanía urbana, los arrieros, los pastores y los jornaleros" (López 1997: 77). 
mayores culpables de las epidemias y catástrofes naturales que padecía la sociedad medieval, ya que Dios castigaba a toda la sociedad con esas catástrofes por los pecados de los pobres, más que por los de los ricos. Eran estos últimos los que tenían que solucionar los problemas eligiendo un santo o una Virgen para pedirle que intercediera ante Dios para que cesaran los problemas causados por los castigos divinos. El mismo don Juan Manuel hizo construir iglesias junto a los castillos de sus señoríos para que sus vasallos pudieran ir a rezar a la Virgen, y Jaime I de Aragón mandó construir iglesias dedicadas a "Nuestra Señora" de la Asunción sustituyendo a las mezquitas musulmanas, en los mismos solares que éstas ocupaban. Por lo tanto, el sentimiento de culpa propio y característico del cristianismo no era igual en toda la sociedad medieval, sino que los nobles y el clero lo hacían recaer principalmente en los más pobres, los villanos o pecheros. Lo que conseguían así era la sumisión de estos y la necesidad de que se encomendaran a Cristo, a la Virgen y a los santos para solucionar los problemas que, por sus pecados y, por tanto, por su culpa, padecía toda la sociedad. La forma de hacerlo era mediante las fiestas patronales y religiosas; así conseguían que las clases populares, el tercer estamento de la sociedad medieval, adoptaran los valores ideológicos de fidelidad, obediencia y sumisión que debían tener con sus señores feudales, los nobles y el clero ${ }^{34}$.

Para que todo esto se consiguiera, no bastaba con los sermones en las iglesias, ni con la predicación. Lo realmente efectivo eran las fiestas, porque en ellas el pueblo llano, mayoritariamente analfabeto en los siglos pasados, veía con sus propios ojos lo que el clero predicaba en los sermones. Cuando la representación de las escenas bíblicas se adornaba con la parafernalia, el lujo, la riqueza y el arte de las manifestaciones religiosas como las fiestas patronales, la Semana Santa o el Corpus Christi (Domene 2001), a los pobres y analfabetos campesinos y jornaleros no les quedaba más remedio que quedarse boquiabiertos y creerse todo lo que en aquellas fiestas se representaba. Esto se aprovechó de una manera muy eficaz en la Contrarreforma, a partir del Concilio de Trento (1545-1563), debido a la necesidad de evangelizar y convencer a la población de los principios dogmáticos de la religión católica frente a la Reforma protestante ${ }^{35}$.

\footnotetext{
${ }^{34}$ Las fiestas patronales son, en alguna medida, la manifestación de la sumisión a un nuevo señor, no ya feudal, que los domina, sino al santo que los protege, pero de algún modo el santo es el señor del pueblo, la Iglesia domina al pueblo a través de sus santos. Algunas fiestas o algunos de sus elementos son una copia de las grandes fiestas políticas celebradas durante la Baja Edad Media en las que la Iglesia intentó dar a conocer o manifestar toda su fuerza y poder. Pertenecen a este grupo de fiestas, las patronales que se celebran en todas las ciudades, villas y aldeas, las fiestas de cofradías y, especialmente, el Corpus Christi (Sánchez 1978: 261-266).

${ }^{35}$ La intención de la Iglesia era proteger a los católicos de la influencia de Lutero y de los reformadores protestantes, así como evangelizar en la ortodoxia católica tridentina a los que todavía no lo eran (como es el caso de los indígenas americanos y filipinos, por ejemplo). Esta finalidad la perseguía el clero demostrando que la religión católica era la verdadera, convenciendo a la población de las cuestiones de fe que los protestantes rechazaban, como es por ejemplo la virginidad de María (antes y después del parto), y fomentando la devoción popular a la Virgen y a los santos (como intermediarios entre Dios y sus criaturas), entre otras cosas, ya que se trataba de reafirmar en los fieles católicos esos dogmas que eran rechazados por Lutero.
} 


\section{LAS FIESTAS PATRONALES COMO INSTRUMENTO DE ADOCTRINAMIENTO DE LA POBLACIÓN}

Igual que las comedias de santos, las fiestas religiosas como las patronales o la Semana Santa tenían una finalidad didáctica e ideológica muy clara: $\operatorname{adoctrinar}^{36}$ a la población enseñándole la ortodoxia de la Contrarreforma y los dogmas que se consideraban fundamentales en la religión católica a partir del Concilio de Trento $^{37}$ (15451563); y tanto el teatro como las fiestas religiosas eran manifestaciones muy adecuadas para ello ${ }^{38}$. Todo ello se vio favorecido por las conclusiones de la XXV sesión del Concilio de Trento (3 de diciembre de 1563), en la que se insistió en la necesidad de que se instruyese al pueblo en la intercesión e invocación de los santos, y de que mediante representaciones plásticas se le recordase los artículos de la fe, los milagros y los ejemplos a imitar ${ }^{39}$. Este enfoque didáctico vino a sumarse a la popularidad que

\footnotetext{
${ }^{36}$ Según el D.R.A.E. (22 edición, 2001), adoctrinar es "tr. instruir a alguien en el conocimiento o enseñanzas de una doctrina, inculcarle determinadas ideas o creencias". Por la connotación negativa de esta palabra, no la utilizamos aquí, sustituyéndola por otras como enseñar o catequizar.

37 La finalidad de la Contrarreforma era, principalmente, catequizar a la población española tras el Concilio de Trento para evitar la influencia protestante; demostrar que la religión católica es la verdadera frente al islam y al protestantismo; fomentar la devoción popular a la Virgen y a los santos, en los que no creían los protestantes, y sacarlos a la calle, en las procesiones y fiestas religiosas y patronales; evangelizar a los indígenas del Imperio español; y legitimar la monarquía absoluta en España y en las colonias, porque el rey de España es el que defiende la religión católica, que es la verdadera. Para conseguir estos fines, en la Contrarreforma se utilizaron principalmente una serie de instrumentos culturales y antropológicos, como eran:

- La potenciación de las fiestas religiosas: el Corpus Christi, la Semana Santa y la Navidad, principalmente. Se sacan las imágenes a la calle y se potencian las procesiones con esas imágenes. También se aprovechan las fiestas patronales de los pueblos (vid. Christian 1972, 1975, 1976, 1978, 1981a y 1981b) y se potencian más todavía, representándose en ellas las obras teatrales de tema religioso.

- El arte barroco de tema religioso: la arquitectura (construcción de iglesias y catedrales), la escultura (imaginería de la Semana Santa y decoración de las iglesias) y la pintura (en la que destacaron sobre todo por su temática religiosa Murillo, Zurbarán, etc.).

- La literatura barroca de tema religioso: principalmente, las obras teatrales, como los autos sacramentales, las comedias de santos, las comedias marianas y las comedias de moros y cristianos. Normalmente, estas obras se representaban coincidiendo con las fiestas religiosas y con las patronales de las ciudades y las villas.

Cuando estos instrumentos culturales no eran efectivos, se utilizaba un instrumento de tipo judicial, el Tribunal del Santo Oficio de la Inquisición, que estaba a cargo de los frailes dominicos (vid. Domene 2013).

38 "De todo lo expuesto hasta ahora, podemos concluir que si bien es innegable que no existe teatro más cercano a la ideología contrarreformista que las comedias de santos, también lo es que es uno de los que más celosamente guardan sus raíces medievales, visible no solo en la profusión de sus recursos escenográficos que podemos encontrar en la mayoría de los textos, sino en la misma configuración de unos protagonistas (los santos), construidos teniendo en cuenta los referentes culturales, las expectativas vitales y los valores personales de los sectores más populares de sus espectadores" (Sirera 2000: 206).

39 "Dentro de esta religiosidad local del siglo XVI español, lo que constituye su núcleo central es el santo patrono y el voto o la promesa. La relación de ambos es fácil de explicar. Ante los azares de la vida de entonces, a saber, las epidemias, las plagas, los desastres económicos por
} 
los santos gozaban en la sociedad española del momento, y que era capaz de generar leyendas hagiográficas que autores como Lope no vacilaron en incluir en sus obras, aceptando así lo que podríamos calificar como santidad vox populi. Por eso, todas las comedias de santos tienen la misma estructura argumental para llevar a cabo esa finalidad ideológica ${ }^{40}$ (Maldonado 1990: 72-73).

La situación cambió con el Racionalismo y la Ilustración, que llevó a los gobernantes a prohibir los excesos de las fiestas religiosas y civiles en base a una nueva concepción del fenómeno festivo que chocaba con la teatralidad barroca. "Fue, sobre todo, a partir de la mediación del siglo XVIII cuando muchas fiestas religiosas populares, y las asociaciones y grupos que las organizan, se escapan del control del poder" (Moreno 1999: 16) porque no aceptan ni obedecen estas prohibiciones, y así surge en esta época, al margen del poder eclesiástico, lo que se conoce como religiosidad popular. Durante los reinados de Carlos III y de Carlos IV, se prohíben las salvas de arcabucería y las soldadescas que participaban en las fiestas patronales, los moros y cristianos, las corridas de toros, e incluso muchos elementos festivos y rituales de las procesiones y cofradías de la Semana Santa. Las prohibiciones no se cumplieron, y las fiestas populares se mantuvieron hasta que cambió completamente la situación con la llegada del sistema liberal y el régimen parlamentario en 1834, tras la muerte de Fernando VII. Empezó entonces el Romanticismo y el costumbrismo y, con él, el interés por las fiestas y costumbres populares, que se refleja en la prensa de la época. Las fiestas populares renacen entonces, favorecidas por la política y la cultura. En la segunda República, como consecuencia de la Constitución de 1932 y de la separación Iglesia-Estado, las fiestas religiosas y patronales pierden el apoyo político, que se recupera con más fuerza y vigor tras la Guerra Civil, como consecuencia del nacionalcatolicismo que caracterizó al régimen franquista; y, con la llegada de la democracia, se produce una auténtica eclosión de las fiestas populares; se las apropia el pueblo,

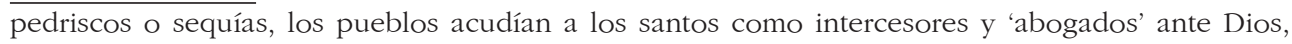
el juez supremo. A cambio, les ofrecían un voto o promesa, es decir, el compromiso de celebrar un día de fiesta en su honor, observando la víspera abstinencia de comer carne, haciendo obras de caridad y homenajeando al santo con una procesión. (...) Como horizonte de fondo podemos constatar aquí una mentalidad popular-teológica articulada en torno a dos polos: el castigo y la gracia. Las gentes de esta época imaginaban a Dios como un poder exterior severo que, cuando era ofendido, había de ser persuadido, mediante actos penitenciales, para que no las castigara. Pero penitencia y persuasión se entendían mejor canalizadas a través de intermediarios como la Virgen y el santo. Ambos se vinculaban a la comunidad local como mensajeros benévolos que les informaban de las alternativas que tenían para evitar los castigos y que intercedían activamente ante Dios por ellos" (Maldonado 1990: 72-73).

40 "La institucionalización de la semana santa en las calles y la creación de cofradías de penitencia, así como la adopción de este modelo por parte de muchas hermandades religiosas ya preexistentes de carácter gremial o étnico, fue, sin duda, algo planificado que fue puesto en práctica en todos los países que continuaron fieles a Roma. Se trataba de reactivar el adoctrinamiento del pueblo para mantenerlo alejado de las doctrinas de la Reforma, utilizando la vía visual y emocional como complemento y, a veces, en la práctica, incluso como sustitución de la palabra. Se trataba de renovar la pedagogía religiosa suscitando la devoción hacia imágenes del Cristo muerto o atormentado y de su Madre con el corazón traspasado por el dolor, que eran acompañadas por flagelantes y penitentes, con túnicas y antifaces, en procesiones que hacían estación en varias iglesias o en la parroquia o catedral de la población respectiva los jueves y viernes santos" (Moreno y Agudo 2012: 172-173). 
se popularizan y masifican, y se convierten en auténticos referentes identitarios de los pueblos y ciudades en el contexto de los nacionalismos políticos surgidos entonces ${ }^{41}$.

El poder político y religioso, por ello, siempre ha intentado controlar y protagonizar estas manifestaciones festivas porque le permitía mantener el orden social establecido $^{42}$, aunque el pueblo también aprovechaba algunas fiestas para subvertirlo simbólica y temporalmente (es el caso del Carnaval, o de otras fiestas como las de los "Obispillos", Els Enfarinats de Ibi [Fernández 2000] o la Festa dels Fols del Camp de Mirra, por poner solo algunos ejemplos). Este carácter subversivo era permitido por el poder como contrapartida necesaria y como válvula de escape de la población frente al control social ejercido por el poder civil y religioso establecido ${ }^{43}$.

\section{CONCLUSIÓN}

Se puede concluir, por tanto, que las fiestas religiosas han tenido, y siguen tenien-

${ }^{41}$ "De todos es conocida, y no voy por tanto a detenerme en ella, la influencia del nacionalcatolicismo franquista sobre las fiestas populares: presión integrista sobre las 'religiosas', a partir del nuevo maridaje Iglesia-Estado, y control estricto y prohibiciones sobre las 'laicas'. El anatema legal contra los carnavales - aunque algunos de ellos no llegaron a desaparecer, en los pueblos y ciudades en que eran el referente principal de la identificación local—, o la censura moral contra los bailes 'agarrados' son buena prueba del intento por domesticar las fiestas populares. A pesar de ello, fue en estas, en no pocos casos, donde únicamente pudieron exteriorizarse en público algunos símbolos nacionalitarios y de clase oficialmente abolidos desde el poder dictatorial. Cuando concluyó este, y se restableció la democracia parlamentaria, las fiestas populares eclosionaron con un vigor que muy pocos esperaban antes del año 1976 y con una participación más amplia que nunca. Contribuyó a ello la propia democratización interna, en mayor o menor grado y con mayores o menores resistencias, de los grupos para el ritual y de las mismas fiestas, y la puesta en primer plano de estas como referentes de identificación. Con lo que los viejos y nuevos poderes, tanto civiles como, en su caso, eclesiásticos, volvieron a prestarles especial atención para intentar capitalizarlas" (Moreno 1999: 18-19).

42 "Es evidente que los poderes establecidos han intentado en todas las épocas protagonizar las fiestas, controlarlas, hacer de estas un medio de reproducción del orden social incluso a través de la puesta entre paréntesis, provisional y controlada, de este. El 'pan y circo', las fiestas organizadas para celebrar nacimientos, bodas y entronizaciones regios, los desfiles y fiestas patrias, y toda una larga serie de fiestas organizadas y controladas desde el poder dan prueba clara de esto. Hoy, las subvenciones oficiales tienen, en muchos casos, la misma intención controladora o al menos reguladora" (Moreno 1999: 16).

43 "Los rituales y elementos de la comúnmente denominada religiosidad popular hay que contemplarlos, dentro de una perspectiva histórica, en el contexto de la permanente imbricación entre dos fuerzas asimétricas pero igualmente presentes y actuantes. La primera corresponde al poder político y a la ideología religiosa dominante que lo legitima, y actúa en la dirección de integrar en el orden social establecido a las clases, etnias y género en posición subalterna de la forma menos conflictiva posible, mediante la obtención de consenso por converger los diferentes grupos en unos mismos símbolos y participar en unos mismos rituales con una fuerte carga ideológica. La segunda, está constituida por las estrategias, tanto activas como no plenamente conscientes, de adaptación, resistencia e incluso a veces rebelión, sobre todo simbólica —según los casos y contextos-, de las clases, etnias y género dominados: campesinos, menestrales, artesanos, trabajadores urbanos y agrícolas, negros, mulatos, moriscos, gitanos, mujeres, homosexuales..., para preservar su propia identidad colectiva y la autoestima individual en un marco caracterizado por la opresión económica y política y por la dominación ideológica” (Moreno 1999: 15). 
do, una función social que consiste en el mantenimiento del orden social estableci$\mathrm{do}^{44} \mathrm{y}$, con él, de los privilegios sociales, políticos y económicos de la clase dominante de cada período histórico mediante la sumisión de las clases populares a la nobleza feudal y terrateniente en el Antiguo Régimen, pero también de la burguesía agraria, industrial y comercial en la España contemporánea ${ }^{45}$. "Las fiestas, sobre todo los rituales religiosos, serían instrumentos alienadores con la función fundamental de ocultar las contradicciones sociales y conseguir la sumisión de los sectores dominados" (Moreno 1999: 19). En la actualidad, a pesar de las reticencias de la jerarquía católica ${ }^{46}$, la religiosidad popular y la devoción a la Virgen ha sido intensificada por los obispos y sacerdotes en los últimos cien años con el fin de contrarrestar el proceso de secularización (Maldonado 1990: 72). Como compensación a esta función de sumisión al poder, se permite en algunas de ellas un carácter secundario de rebeldía o subversión al orden social, atenuado o incluso suprimido por los gobiernos más autoritarios ${ }^{47}$. A

\footnotetext{
${ }^{44}$ Como decía Miguel Artola (1991: 112), es así como la sociedad rural "experimenta las consecuencias de una intensa acción socializante por parte de la Iglesia, que no solo predica la salvación individual sino que, al mismo tiempo, justifica el orden establecido e interviene, con especial eficacia, en el control de las conductas desviadas y el castigo de los delitos de opinión". Y es así, gracias a esta acción socializante de la Iglesia, la religiosidad popular y las fiestas religiosas, como se explica que "la sociedad del Antiguo Régimen, sometida a la autoridad de monarcas absolutos, disfrutó de una estabilidad que solo interrumpen revueltas de gran violencia — comunidades, germanías, alteraciones de mediados del siglo XVII, motín de Esquilache- pero carentes de continuidad".

${ }^{45}$ La religiosidad popular, profundamente enraizada en la población española y mediterránea en general, ha sido utilizada por la Iglesia y por las clases poderosas hasta el Concilio Vaticano II (1962-1965). A partir de entonces, fue menospreciada por la Teología oficial por considerarla superficial y supersticiosa. Sin embargo, tras el Concilio, en los años setenta y ochenta, ha habido una descristianización patente de la sociedad española, con un incremento notable del número de agnósticos y ateos, y un abandono o absentismo de las iglesias por parte de muchos creyentes, que ha contrastado con el aumento espectacular de la participación en las fiestas religiosas y patronales de los pueblos (las romerías, las procesiones de la Semana Santa, etc.), organizadas muchas veces por seglares (cofradías, hermandades, etc.). Ahí está la popularidad de la Romería del Rocío o la Semana Santa, por ejemplo. Esto ha hecho reaccionar en los noventa a la jerarquía de la Iglesia, que la ha vuelto a tener en cuenta y a intervenir activamente en las entidades organizadoras de las fiestas religiosas para atraer de nuevo a los creyentes a la Iglesia oficial a través de ellas, bien directamente, a través de los párrocos, o de forma indirecta, a través de las comunidades seglares de fieles más leales a la jerarquía eclesiástica.

46 "La llamada religiosidad popular desde la perspectiva oficial es considerada imperfecta cuando no desviada, que aunque tiene algo de positivo, siempre -dicen- habrá que limpiarla de adherencias erráticas, tradiciones, creencias y ceremonias superfluas y contaminadas. Y es que la institución eclesiástica soporta a duras penas la religión no eclesiástica, pues como dice el jesuita y filósofo de la religión Gómez Caffarena: "La autoridad eclesiástica..., no está sin más con la religiosidad popular, la cultiva como indispensable clientela" (1993). En los últimos decenios se percibe una valoración positiva por parte de la jerarquía, aunque siempre con recelo, porque no la controla en todos sus aspectos, así para el obispo Asenjo de Córdoba, hoy arzobispo de Sevilla, la religiosidad popular es sobre todo un freno a la secularización (Sierra Albarrana 2007)" (Rodríguez 2011: 37).

47 "En el otro extremo, las fiestas tendrían un fondo primigenio de espontaneísmo, libertad y contacto místico y/o lúdico con lo inmanente que les daría un carácter esencialmente extrasocial que sería el que las fuerzas sociales dominantes estarían empeñadas en desnaturalizar mediante el control del ritual" (Moreno 1999: 19).
} 
esta función social, se le suma el carácter de las fiestas como signo de identidad de los pueblos y ciudades donde se celebran ${ }^{48}$.

\section{BIBLIOGRAFÍA CITADA}

Ariño Villarroya, Antonio. 2007. "La religión común: el caso de la Navidad", en Manuel Pérez Yruela et al. (coords.), Escritos sociológicos: en homenaje a Salvador Giner: 185-212. Madrid: Centro de Investigaciones Sociológicas.

Ariño Villarroya, Antonio y Pedro García Pilán. 2006. "Apuntes para el estudio social de la fiesta en España". Anduli: Revista andaluza de ciencias sociales 6: 13-28.

Ariño Villarroya, Antonio y Sergi Gómez i Soler. 2012. La festa mare. Les festes en una era postcristiana. Valencia: Museu Valencià d'Etnologia.

Artola Gallego, Miguel. 1991. Antiguo Régimen y revolución liberal. Barcelona: Ariel.

Castilla Vázquez, Carmen. 1999. "Las fiestas patronales como ritual para la reproducción de identidades", en Manuel Oliver Narbona (coord.), Jornadas de Antropología de las Fiestas. Identidad, mercado y poder: 155-163. Sueca: Expofiesta: Feria Nacional de las Fiestas Populares.

Christian, William A. 1972. Person and God in a Spanish Valley. Princeton: Princeton University Press.

Christian, William A. 1975. "Santuarios", en Quintín Aldea, Tomás Marín y José Vives (eds.), Diccionario de Historia Eclesiástica IV: 2205-2207. Madrid: CSIC.

Christian, William A. 1976. De los santos a María. Panorama de las devociones a santuarios españoles desde el principio de la Edad Media hasta nuestros días. Madrid: Temas de Antropología Española.

Christian, William A. 1978. Religiosidad popular. Estudios antropológicos en un valle español. Madrid, traducido por E. Luque.

Christian, William A. 1981a. Local Religion in Sixteenth Century Spain. Princeton: Princeton University Press.

Christian, William A. 1981b. Apparitions in Late Medieval and Renaissance Spain. Princeton: Princeton University Press.

Delgado, Manuel. 1992. La ira sagrada. Anticlericalismo, iconoclastia y antirritualismo en la España contemporánea. Barcelona: Ed. Humanidades.

Domene Verdú, José Fernando. 1999. "Historia e identidad en el origen de las fiestas de moros y cristianos", en Manuel Oliver Narbona (coord.), Jornadas de Antropología de las Fiestas. Identidad, mercado y poder: 165-180. Sueca: Expofiesta. Feria Nacional de las Fiestas Populares.

Domene Verdú, José Fernando. 2000. "La proclamación de la Virgen de las Virtudes como Patrona de Villena no fue en 1474, sino en 1476". Día cuatro que fuera: 248-256. Villena: Junta Central de Fiestas.

Domene Verdú, José Fernando. 2001. "La función social de las fiestas religiosas: El Corpus Christi y la fiesta patronal de Villena en la Edad Moderna", en Manuel Oliver Narbona (coord.), III Jornadas de Antropología de las Fiestas. Antropología de la Fiesta: 123-136. Elche: Instituto Alicantino de Cultura Juan Gil-Albert e Institución Ferial Alicantina.

Domene Verdú, José Fernando. 2006. "Historia de las Fiestas de Moros y Cristianos de Villena", en José Fernando Domene Verdú, Miguel Ángel González Hernández y Vicente Vázquez Hernández (coords.), Las fiestas de moros y cristianos en el Vinalopó. Collecció L'Algoleja no ${ }^{\circ}$. Alicante: Centre d'Estudis Locals del Vinalopó.

Domene Verdú, José Fernando. 2008. Historia de las Fiestas de Moros y Cristianos de Villena. Los textos de las Embajadas y la Conversión en la Historia de las Fiestas de Villena. Villena: El Periódico de Villena.

\footnotetext{
48 "Creo más útil contemplar los rituales festivos, sobre todo hoy, no tanto como fundamentalmente insertos en el ámbito ideológico — aunque lo ideológico esté sin duda claramente presente- sino en el identitario. Tanto los que poseen claras significaciones y/o significantes religiosos como los que no, representan hoy, fundamentalmente, contextos y ocasiones donde se reafirman, reproducen y redefinen identidades e identificaciones colectivas" (Moreno 1999: 19).
} 
Domene Verdú, José Fernando. 2013. Teatro religioso en las fiestas de Villena. Las representaciones teatrales dedicadas a la Virgen de las Virtudes. Villena: Asociación de Ntra. Sra. de las Virtudes.

Domene Verdú, José Fernando. 2015. Las fiestas de moros y cristianos. San Vicente del Raspeig: Publicacions de la Universitat d'Alacant.

Domínguez Ortiz, Antonio. 1976. Sociedad y Estado en el siglo XVIII español. Barcelona: Ariel.

Fernández Ardanaz, Santiago. 1999. "Santuarios de Cuevas y Santerón: rituales festivos de identidad y alianza. Expresión de antiguas federaciones prerromanas", en Manuel Oliver Narbona (coord.), Jornadas de Antropología de las Fiestas. Identidad, mercado y poder: 109-132. Alicante: Instituto Alicantino de Cultura Juan Gil-Albert, Institución Ferial Alicantina.

Fernández Ardanaz, Santiago. 2000. "Els Enfarinats (Ibi, Alicante)", en Manuel Oliver Narbona (coord.), Jornadas de Antropología de las Fiestas. Antropología de la Fiesta: 343-359. Sueca: Expofiesta: Feria Nacional de las Fiestas Populares.

Frazer, James George. 1890 [1981]. La rama dorada. Magia y religión. Madrid: Ediciones FCE España, S. A.

Gramsci, Antonio. 2010. Las maniobras del Vaticano. Buenos Aires: Ediciones Godoy. Colección Exhumaciones. 128 pp.

López Serrano, Aniceto. 1997. Yecla: Una villa del Señorío de Villena (siglos XIII al XVI). Yecla: Real Academia Alfonso X el Sabio.

Maldonado, Luis. 1990. Para comprender el catolicismo popular. Estella. Ed. Verbo Divino.

Martínez Espín, Francisco Mariano y Sebastián Campillo Frutos. 2000. "Creencias paganas versus cristianas: un caso de sincretismo cultural: la celebración de la fiesta de la Candelaria", en Manuel Oliver Narbona (coord.), Jornadas de Antropología de las Fiestas: 173-188. Alicante: Instituto Alicantino de Cultura Juan Gil-Albert, Institución Ferial Alicantina.

Moreno, Isidoro. 1997. La antigua hermandad de los negros de Sevilla: etnicidad, poder y sociedad en 800 años de historia. Sevilla: Universidad de Sevilla.

Moreno, Isidoro. 1999. "Poder, mercado e identidades colectivas: las fiestas populares en la encrucijada", en Manuel Oliver Narbona (coord.), Jornadas de Antropología de las Fiestas. Identidad, mercado y poder: 11-22. Sueca: Expofiesta: Feria Nacional de las Fiestas Populares.

Moreno, Isidoro. 2002. "La Semana Santa: más allá del fervor religioso". Clío: Revista de Historia 5: 80-87.

Moreno, Isidoro. 2005. "Plurietnicidad, fiesta y poder: cofradías y fiestas andaluzas de negros como modelo para la América colonial", en Antonio Garrido Aranda (coord.), El mundo festivo en España y América: 169-188. Córdoba: Servicio de Publicaciones de la Universidad de Córdoba.

Moreno, Isidoro. 2006. La Semana Santa de Sevilla: conformación, mixtificación y significaciones. Sevilla: Instituto de la Cultura y las Artes.

Moreno Navarro, Isidoro y Juan Agudo Torrico. 2012. "Las fiestas andaluzas", en Isidoro Moreno Navarro y Juan Agudo Torrico (coords.), Expresiones culturales andaluzas: 165-217. Sevilla: Aconcagua Libros.

Pretel Marín, Aurelio. 1999. "Almansa en el Estado medieval de Villena", en Musulmanes y Cristianos en Almansa. De la historia a la fiesta. Marzo 1998, Jornadas de estudios locales 2. Octubre 1999.

Prieto de Paula, Ángel Luis y José Fernando Domene Verdú (eds.). 2014. Rodrigo Gabaldón. Comedias Marianas. Los reflejos esclarecidos del sol coronado de astros, María de las Virtudes, en el cenit de Villena ( I y II). San Vicente del Raspeig: Publicaciones de la Universidad de Alicante.

Rodríguez Becerra, Salvador. 1999. "Fiestas de mayo en Andalucía. Tradición y cambio en un ritual popular", en Manuel Oliver Narbona (coord.), Jornadas de Antropología de las Fiestas. Identidad, mercado y poder: 45-56. Sueca: Expofiesta: Feria Nacional de las Fiestas Populares.

Rodríguez Becerra, Salvador. 2011. "Nuevas perspectivas sobre la religiosidad popular o religión común de los andaluces". Revista Murciana de Antropología 18: 31-41.

Sánchez Herrero, José. 1978. La diócesis del Reino de León. Siglos XIV y XV. León: Centro de Estudios e Investigación San Isidoro y Archivo Histórico diocesano de León: 261-266.

Sirera, Josep Lluis. 2000. "La comedia de santos española: un puente entre el teatro medieval y el del barroco", en M. Chiabò y F. Doglio (coords.), XXIV Convegno Internazionale Martiri e Santi in Scena, Anagni 7-10 settembre 2000: 179-206. Anagni: Centro Studi sul Teatro Medioevale e Rinascimentale. 
Suárez Moreno, Francisco. 1999. "La fiesta del Charco: vicisitudes de una pervivencia aborigen canaria", en Manuel Oliver Narbona (coord.), Jornadas de Antropología de las Fiestas. Identidad, mercado y poder: 191-204. Sueca: Expofiesta: Feria Nacional de las Fiestas Populares.

Velasco Maillo, Honorio M. 1982. "Fiestas de mayo en la tierra de Alcalá", en Honorio M. Velasco, Tiempo de Fiesta. Ensayos antropológicos sobre las fiestas en España: 169-203. Madrid: Editorial "Tres-Catorce-Diecisiete". Colección Alatar.

Velasco Maillo, Honorio M. 1989. "Las leyendas de hallazgos y de apariciones de imágenes: Un replanteamiento de la religiosidad popular como religiosidad local", en María Jesús Buxó i Rey, Salvador Rodríguez Becerra y León Carlos Álvarez y Santaló (coords.), La religiosidad popular 2: 401-410.

Velasco Maillo, Honorio M. 1996. "La apropiación de los símbolos sagrados: historias y leyendas de imágenes y santuarios (siglos XV-XVIII)". Revista de antropología social 5: 83-114.

Velasco Maillo, Honorio M. 1999. "Imágenes y santuarios: una aproximación desde los relieves y las sombras de los relatos histórico-legendarios", en Salvador Rodríguez Becerra (coord.), Religión y cultura 2: 13-28. Sevilla: Junta de Andalucía. Consejería de Cultura. Fundación Antonio Machado.

Velasco Maillo, Honorio M. 2000. "Las leyendas de Hallazgo y de Singularización de Imágenes Marianas en España: una aproximación a la categoría de imagen-persona", en David González Cruz (coord.), Religiosidad y costumbres populares en Iberoamérica: actas del Primer Encuentro Internacional celebrado en Almonte-El Rocío (España) del 19 al 21 de febrero de 1999: 89-102. Huelva: Universidad de Huelva, Servicio de Publicaciones.

Vigil, Marcelo. 1985. "Edad Antigua”. Historia de España Alfaguara I: 185-468. Madrid: Alianza Editorial Alfaguara.

Zapater Ugeda, José. 1884. Historia de la Imagen de Ntra. Sra. de las Virtudes. Villena. 2. ed. 1974.

Fecha de recepción: 2 de febrero de 2016

Fecha de aprobación: 20 de julio de 2016 